\title{
THE EFFECT OF PRICE SHOPPING \\ IN MEDICAL MARKETS: \\ HOSPITAL RESPONSES TO \\ PPOs IN CALIFORNIA
}

Jonathan Gruber

Working Paper No. 4190

\section{NATIONAL BUREAU OF ECONOMIC RESEARCH 1050 Massachusetts Avenue \\ Cambridge, MA 02138 \\ October 1992}

I am grateful to Josh Angrist, Steven Berry, Andy Bindman, David Dranove, Andrea Gruber, Rachel Friedberg, Ciaran Phibbs, Ceci Rouse, Jon Skinner, Doug Staiger, Larry Summers, Mike Whinston, numerous seminar participants, and especially David Cutler, Larry Katz, Joe Newhouse, and Jim Poterba for helpful discussions and comments. I am also grateful to ABT Associates, Grace Carter, Doug Staiger, and Ken Langa for providing data. I acknowledge financial support from the Sloan Foundation, the Harvard Chiles Fellowship, and the Harvard Institute for Economic Research. This paper is part of NBER's research program in Health Care and Public Economics. Any opinions expressed are those of the author and not those of the National Burcau of Economic Research. 
NBER Working Paper \#4190

October 1992

\section{THE EFFECT OF PRICE SHOPPING \\ IN MEDICAL MARKETS: \\ HOSPITAL RESPONSES TO \\ PPOS IN CALIFORNIA}

\section{ABSTRACT}

The last ten years have seen the introduction of price shopping into medical markets which were previously dominated by price insensitive consumers. Price shopping has been facilitated by the advent of the Preferred Provider Organization (PPO), which coordinates the demand of a large number of individual health care buyers, thereby gaining market power which it uses to obtain steep discounts off list prices from providers. I study hospital responses to the advent of price compctition in California over the 1984-1988 period. I note that, due to the nature of hospital bargaining with PPOs, hospitals should face more competitive pressure in hospital markets that are more competitive ex-ante. This hypothesis is supported by the fact that hospital net prices declined in more ex-ante competitive areas in California after the arrival of PPOs. Hospital average costs did not decline in more competitive areas, however, indicating that there was a reduction in hospital markups. Care to the uninsured by hospitals. which is financed out of markups, fell substantially as competitive pressure grew; there was a 50 cent reduction in uncompensated care for every one dollar rise in discounts to private payers.

Jonathan Gruber

MIT Department of Economics

E52-274c

Cambridge, MA 02139

and NBER 
The dramatic rise in health care expenditures in the United States, with the medical sector growing from $4.5 \%$ of GNP to $12 \%$ of GNP over the last forty years (Newhouse, 1992), has led to many proposals for reform of our health care system. One approach which has received much recent attention is the "managed competition" model (Butler and Haislmaier, 1989; Enthoven and Kronick, 1989). A key perceived failing of the traditional indemnity model of insurance, under which insurers would pay the billed charges of any source of health care chosen by individuals, was that there was no incentive for price shopping across medical providers by consumers. By introducing incentives for such shopping, the managed competition advocates argue, we can bring the forces of market competition to bear on the medical sector, and efficiency increases in medical production will naturally follow. Opponents of managed competition respond that the lessons of competition in other markets cannot be so readily applied to medical markets, and that the inflationary tendencies of our health care system can only be addressed through a more regulatory approach.

What is often not recognized in this debate, however, is that the move towards price shopping in medical markets has already begun. The key event was the removal, the early 1980s, of state-level barriers to insurers' ability to restrict an individual's choice of provider. These regulations made it impossible for insurers to exercise their market power to shop arnongst providers on the basis of price, and their removal has precipitated a major change in the structure of private health insurance. The mechanism which insurers have used to facilitate price shopping is the Preferred Provider Organization, or PPO. PPOs act as middlemen between individual buyers and providers of health care. By coordinating the demand of a large number of buyers, PPOs gain market power which they use to obtain steep discounts off list prices from health care providers. In return for these discounts, PPOs use 
tinancial incentives to the enrolled group to channel patients to the "preferred" providers. PPO potential enrollment has grown by a factor of 20 since 1984, and one in 3 insured employees now has a PPO option in their health insurance plan. ${ }^{1}$ This rapid growth of PPOs suggests that the experience of recent years provides a valuable opportunity to study the effects of market competition on the delivery of health care.

In this paper, I study hospital responses to the introduction of price competition in California over the $1984-1988$ period. California's regulatory barriers to price shopping by insurers were removed in 1983, and PPOs grew rapidly thereafter; between 50 and $70 \%$ of all privately insured employees in the state now have a PPO option in their health care plans. ${ }^{2}$ The effect on hospital pricing has been dramatic. Figure 1 plots the growth in discounts to private payers (as a fraction of gross patient revenues), and the growth in PPO enrollment, in California over time. ${ }^{3}$ Roughly constant as a fraction of revenues until 1984, discounts have grown by over $900 \%$ since. This growth corresponds to the period of sizeable PPO enrollment growth in California, following the 1983 enabling legislation.

'PPO enrollment is not easily measured, workers have financial incentives to choose the preferred provider, but they may go anywhere they like. The only available figure is "potential enrollment", which is the number of workers who have a PPO option in their health insurance plan; the takeup rate on this option is estimated to be 55-60\% (Rice et al., 1986).

2PPO location data from Marion Merrill Dow (1990). Enrollment growth from Johns (1989); current level from author's calculations from data in Arstein-Kerslake (1988).

${ }^{3}$ Aggregate discounts from data from Office of Statewide Health Planning and Development (various years). Discounts to PPOs only are not available, so total discounts to private payers are used; see the discussion in Part III. PPO enrollment from Johns (1989). The two series are normalized so that each equals one in 1984, and then logged. 
I proceed by modelling price competition among hospitals as being a function of ex-ante market concentration. Since PPOs must make themselves attractive to local potential enrollees, a given hospital's bargaining power with a PPO will largely be a function of that hospital's share of the local output market. That is, in more ex-ante competitive output markets, where PPOs can be more selective in choosing providers while retaining their attractiveness to potential enrollees, hospitals should be forced to give larger price concessions to the PPO. ${ }^{4}$ I confirm this conjecture by showing that hospital discounts have grown the most, and net prices have fallen the most, in the most ex-ante competitive markets.

Having established that ex-ante competition proxies for the effects of "injecting" price competition into hospital markets, I then ask what effect price competition has had on hospital behavior. Proponents of market competition have highlighted the potential of price shopping for restraining health care cost growth. However, I note that hospital net prices to insured patients are the sum of two components: costs and markups. In the short run, it is not obvious which of these components will adjust as prices fall. In fact, I find that hospital costs did not fall in more competitive markets over the 1984-1988 period. This inability of price competition to lower costs differs from the experience of Medicare's Prospective Payment System (PPS), a government cost containment program which led to a large fall in hospital costs over this era. I discuss how this may have been a natural consequence of the relative incentives to change patient treatment quality under PPS versus shopping by PPOs.

If average costs are unchanged, then the fall in net prices must be coming out of markups to PPO patients. Reduced markups, however, do not

"This prediction also requires assumptions on the nature of ex-ante competition, as I discuss below. 
simply represent a transfer from the hospital to the PPO, due to the role of the revenues eaned from private payers in supporting care for the uninsured. Hospital charges to the uninsured are often not paid directly by that group, but are cross-subsidized through higher charges to insured payers. I find evidence of a significant reduction in hospital uncompensated care in more competitive markets after the arrival of PPOs. I estimate that hospital uncompensated care fell by approximately 50 cents for every dollar given in discounts to private payers.

The paper proceeds as follows. In Part I, I present my argument for why price shopping may be the most effective in the most ex-ante competitive markets. In Part II, I introduce the empirical framework. I then examine the elfect of increased price shopping on hospital prices (Part III), costs (Part IV), and uncompensated care (Part V). Part VI concludes by discussing the implications of my findings for a welfare analysis of the managed competition strategy.

\section{PART I: PRICE SHOPPING AND EX-ANTE COMPETITION}

The basic premise of the empirical work is that price shopping will be the most effective, in terms of obtaining lower net prices, in the most exante competitive, or least concentrated, hospital markets. While this assumption has been made in several recent studies of hospital markets, it has not been theoretically justified. ${ }^{5}$ In the four sections of this Part, I argue that

\footnotetext{
${ }^{5}$ Dranove et al. (1992) discuss the switch from "patient-driven" competition to "payor-driven" competition, and provide evidence that the perverse price/concentration relationship discussed above reversed in California between 1983 and 1988. Zwanziger and Melnick (1988) refer to the change as a switch from quality competition to price competition, and show that the perverse cost/concentration relationship in Califomia disappeared as well over these years. However, neither paper discusses why it is most
} 
this is a sensible assumption. I first introduce the prevailing theories of hospital markets before the introduction of price shopping, and then discuss the way in which PPOs facilitated shopping in these markets. I then illustrate why ex-ante competitive markets should be the most fertile ground for price shopping once PPOs are introduced; that is, why ex-ante actual competition is a reasonable proxy for potential price competition. Finally, I show that, given that price shopping is most intense in the most ex-ante competitive markets, we would expect prices to fall there under a set of models of the exante equilibrium. I note, however, that this last prediction is not universal; there are specifications of the ex-ante equilibrium which do not yield a strong prediction about the relation between ex-ante competition and the change in price.

\section{Hospital Markets Before Price Shopping}

Existing models of the hospital market are motivated by three key features of this market. First, there is a broad consensus that there was little price competition among hospitals before the 1980s. This was primarily due to three related phenomena. Individuals were largely covered from their first dollar of hospital expenditure under private health insurance, so there was little incentive to shop. ${ }^{6}$ Furthermore, patients lacked the informational resources necessary to search effectively across medical care providers. Finally, those few patients who did have the incentives and resources necessary to shop for low prices did not have the market power necessary to affect hospital pricing;

natural to use ex-ante actual competition to proxy for ex-post price competition.

${ }^{6}$ In 1980 , the average coinsurance rate for hospital services was only $5.2 \%$ (Newhouse, 1992). Furthermore, 94\% of insured employees had the full cost of their health insurance paid by their employers in 1979 (author's tabulations from March 198u Current Population Survey). 
the inframarginal losses to hospitals on their existing patient base from lowering prices would exceed any gains from adding this small number of new patients (Frech, 1985).

The second relevant feature is that a key determinant of patient demand is distance to the provider. A recent study of patient choice across hospitals (Luft et al., 1990) estimated that a 10\% reduction in the distance from a consumer to a provider would increase the probability of the consumer going to that hospital by $13 \%$; distance was the most consistently important predictor of patient choice in their conditional choice logit model. As a result, hospital markets are very localized.

Finally, hospital prices and average costs are no lower, and may in fact be higher, in more competitive hospital markets. ${ }^{7}$ This reversal of the standard Industrial Organization price/concentration relationship is robust to detailed controls for differences across markets in the cost of inputs and other area characteristics, and has motivated the two main models of the hospital market in the era before price competition.

The first is the informational imperfections model of Satterthwaite (1979)..$^{8}$ He models the medical marketplace as being under monopolistic competition, due to the individualized nature of the product, and the presence of imperfect and costly information. In such a model, markups are a function of the elasticity of demand facing each seller. However, this elasticity is determined by the idiosyncracies of consumer search, rather than by the degree of market concentration. Satterthwaite argues that information on providers

'See Robinson and Luft (1985) for recent evidence on costs; Noether (1988) and Dranove et al. (1991) for recent evidence on prices; and Wooley and Frech (1989) for a review of the evidence. In my data, both costs and prices are higher in the ex-ante equilibrium in more competitive markets.

${ }^{8}$ This discussion of Satterthwaite's model follows Dranove et al. (1992). This model refers to physician markets, but it applies equally well to hospitals. 
is no better in more concentrated markets, and may in fact be worse, since a consumer desires overlapping recommendations before using a provider, and the probability of such overlap falls as the number of providers in the market rises. Thus, the relation between market concentration and price will be weak or perverse (Satterthwaite predicts the latter). ${ }^{9}$

The second popular model is the quality competition, or "medical arms race" model, as described in Robinson and Luft (1985). Since patients are primarily referred to hospitals by their physicians, hospitals compete with one another through provision of expensive clinical services to attract physicians, or quality. This medical arms race has the natural implication that average costs should be higher in more competitive markets; however, prices are indeterminate. There are two extensions to this model which predict the level of prices. First, it may be that insurers simply allowed a fixed markup on hospital costs, so that prices will be highest in the most competitive markets as well. Alternatively, some recent papers which have found that costs are higher in more competitive markets, but that prices are the same across markets, have suggested that quality and price competition were acting simultaneously (Noether, 1988; Woolley and Frech, 1989). That is, the medical arms race was leading to higher quality and thus costs, while hospitals also competed away their markups in more competitive markets in order to attract patients. However, these models have not explained how price competition operated, given the barriers to price shopping by patients described above.

\section{The Introduction of PPOs and Price Shopping}

\footnotetext{
${ }^{9}$ As developed by Satterthwaite, this model does not offer predictions about the correlation between market concentration and hospital costs. If we assume, for example, the prices are highest in the most competitive markets, and that hospital administrators prefer to produce a high quality/high cost product, then costs will be higher in more competitive markets as well.
} 
The nature of the hospital market changed dramatically in the mid1980s, with the introduction of the Preferred Provider Organization. PPOs organize, or are organized by, groups of insured individuals (generally employment-based) to negotiate a package of fees and services with local health care providers. PPOs selectively contract with physicians and hospitals, negotiating reduced fees in return for channelling their patient base to the provider. The reductions obtained by PPOs are generally in the form of discounts off of list prices or reduced per diem rates, rather than the fixed price per admission strategy employed, for example, by Medicare under its PPS program. While over $80 \%$ of PPOs used discounts as one of their reimbursement methods in 1989, only $20 \%$ used fixed prices (Marion Merrill Dow, 1990).

While PPOs' market power derives from their ability to channel patients to preferred providers, members of the groups enrolled in PPOs are not forced to choose from this set of doctors and hospitals. Rather, financial incentives, such as reduced copayments or deductibles, are used to induce patients to select one of these providers. Employees are thus offered an element of choice which is absent from the Health Maintenance Organization (HMO) model, which attempts to control costs by managing care from one central source. This may explain the rapid acceptance of PPOs in the late 1980s as HMO enrollment growth has slowed. PPOs therefore both provide a means of shopping among providers on the basis of price, and of introducing price incentives for consumers to choose the low cost providers. They thus, in the words of Dranove et al., "inject" price competition into the medical marketplace. Hospitals now have a strong incentive to offer lower prices to PPOs, for two reasons. First, PPOs may be actually be able to deliver more patients if the hospital becomes a member of the preferred panel, so, perhaps for the first time, hospitals face a non-trivial price elasticity. Second, hospitals are able to price discriminate between PPO members and 
other patients through discounts to PPOs, so that there will be no inframarginal loss in revenue from other private pay patients. Evidence that hospital prices have responded to this injection is provided by Figure 1.

Why did PPOs not develop until the mid-1980s? The primary reason appears to have been laws which did not allow insurance companies to interfere with patients' choice of providers, which effectively prevented these companies (the largest current sponsors) from establishing PPOs. California allowed insurance companies to selectively contract beginning in July, 1983, and PPOs began to grow in that state shortly thereafter. Such enabling legislation has now been passed in 27 states (Hinden, 1989), and in 19 others, current insurance regulations are not viewed as prohibiting the growth of PPOs. In the five states where insurance coverage is still viewed as prohibiting such growth, there has been little PPO development. ${ }^{10}$

\section{Price Shopping Across Medical Markets}

In this section, I show that it is natural to expect that the price elasticity of demand of consumers should increase the most in the most ex-ante competitive markets. This claim is based on a key institutional feature of PPOs: they must offer a product which is attractive to local consumers. As Johns et al. (1985) point out in their detailed review of PPO selection criterion, PPO managers "do not necessarily want to disrupt current utilization patterns by channeling patients to less expensive providers. Rather, they prefer to negotiate better prices from the hospitals and physicians that current and potential policyholders prefer to use" (p. 83). And a RAND study of individual selection of PPO options in their health plans shows that the single

${ }^{10}$ Marion Merrill Dow (1989) presents data on PPO enrollment by state, which is significantly lower for the five states which Rolph et al. (1986) classify as states where PPOs may have problems developing given existing insurance regulations (and which did not pass enabling legislation subsequent to 1986 , according to Hinden, 1989). 
most important predictor of PPO "takeup" was whether the PPO panel included the individual's prior source of care (Hosek and Marquis, 1990). In fact, the least successful PPO, in terms of attracting enrollees, in their study was the one which was most restrictive in its selection of providers."

The fact that PPOs must make themselves attractive to enrollees in a localized hospital market has the following important implication: a hospital's bargaining power in negotiating with a PPO is a function of its market power in the output market. To see why, consider first the case where there is one PPO, who has organized some portion of the potential patients in the hospital's area. Now, consider a (perhaps rural) hospital which has a monopoly in its local market. Patients in this market area will not sign up for the PPO unless that hospital is included in the preferred panel, since they will not travel out of the local market to seek their care. Thus, the monopolist hospital has become a monopsonist with respect to the PPO; its power in the input (potential patients) market is directly tied to its share of the output (actual patients) market.

Contrast this to the case of a less concentrated hospital market. In this market, the PPO does not make its product much less attractive to potential enrollees by excluding any one hospital. Since there are a number of other hospitals to which individuals would be equally satisfied to go, any given provider in a less concentrated market will have less bargaining power vis-a-vis the PPO. Thus, once again, hospital bargaining power is a function of the share of the local output market; a competitive firm in the output market has less market power in the input market as well. ${ }^{12}$ That is, the price

"Although this was also the PPO with the smallest incentive to enroll.

${ }^{12} \mathrm{~A}$ parallel example is that of a union, which has organized workers in a local area who are unable to travel, and which negotiates with a producer of a good which has a local market only (ie. vegetables in the era before 
elasticity of demand of consumers increases the most in the most competitive markets, since PPOs have more alternatives from which to choose, subject to the constraint of including a sufficient portion of the area's providers in order to attract enrollees.

It is important to note that, since PPOs must sell themselves to enrollees, the reason why a given market is a monopoly market or a competitive market ex-ante is irrelevant. All that matters is that PPOs must respect the force that has created that market structure. This argument has the important (and testable) implication that the observed pattern of patient choice should not change dramatically once PPOs are introduced into the market; monopoly hospitals ex-ante should remain monopoly hospitals ex-post. I present evidence consistent with this implication below, when I define my measure of competition. ${ }^{13}$

\section{Increased Shopping and Net Prices}

The final step in my argument is to show that the insreased price shopping will lead to net prices falling the most in the most competitive markets. A larger increase in the elasticity of demand in competitive markets does not guarantee that prices will fall the most there. Generally, ex-ante

refrigerated transportation). In that case, once again, a monopolist in the output market (the only farm in town) will be a monopsonist in the input market as well.

${ }^{13}$ The model is more complicated when we consider the fact that there are likely to be more PPOs in more competitive hospital markets as well. To the extent that PPOs compete to sign up hospitals by requiring a smaller discount to be a preferred provider, this will mitigate their bargaining power advantage vis-a-vis hospitals in competitive markets. However, to the extent that PPOs must compete to sign up area employees by offering lower prices for hospital utilization, this will increase their need to demand lower discounts from providers. That is, introducing another PPO into a given market results in a reduction of both the monopsony and monopoly power of the existing PPO; the net effect on the PPO's bargaining position is unclear. 
prices should be closer to marginal costs in these markets as well, leaving less rents for the PPO to negotiate over. This countervailing effect should make the ultimate relation between output/input market concentration and the negotiated price uncertain. However, in the hospital market, there are a number of models (and a host of empirical evidence) which suggest that prices are no closer to marginal costs in more ex-ante competitive markets, so that, in fact, prices will fall the most there.

Consider first the Satterthwaite monopolistic competition model. ${ }^{14}$ In that model, prices are no closer to marginal costs in more ex-ante competitive markets, and markups may even be higher in these markets. Thus, the increase in the elasticity of demand in competitive markets would be - expected to lower markups and prices there, relative to more concentrated markets. Now consider the quality competition model, with fixed markups. In this case, once again, prices are no closer to marginal costs in more ex-ante competitive markets, so they will fall farthest there as the price elasticity of demand rises the most. One might object that, if the nature of competition changes from quality to price competition, then it is misleading to use ex-ante quality competition to measure potential price competition. This highlights the importance of the discussion above. PPOs did not change the nature of competition; competition on quality dimensions persists into the new era. What has changed is that price competition now exists as well. Thus, markups will be squeezed, while costs should remain largely unchanged.

It follows from this last point, however, the quality competition model with ex-ante price shopping will therefore not lead to the prediction that prices will fall in competitive markets. In this model, markups are already lower in competitive markets, so that there will be uncertainty as to the ultimate effect.

${ }^{14}$ The effect of introducing price competition within the context of this monopolistic competition model was first discussed by Dranove et al. (1986). 
Thus, the ultimate effect of ex-ante competition on the change in prices is a function of the "correct" model of the ex-ante hospital market, and remains an empirical question. The goal of Part III is to demonstrate that prices did in fact fall more in more competitive markets. In order to do so, Part II presents the data, defines the key regressor, and discusses my identification strategy.

\section{PART II: DATA, MEASUREMENT, AND IDENTIFICATION}

\section{STRATEGY}

$\underline{\text { Data }}$

I primarily use two sources of data which are provided by the Califomia Office of Statewide Health Planning and Development: the Hospital Disclosure Report and the Hospital Discharge Dataset. The disclosure report is a detailed annual report on hospital finances, gross utilization statistics, and facilities; there are roughly 10,000 variables for each California hospital in each year. These data are audited for consistency by the state. The discharge dataset contains a small number of variables (some demographics, payer type, and diagnostic and procedural data) for each inpatient admission to California hospitals in a year (roughly 3.5 million observations). I use each of these data for the years 1982,1984, and 1988. I also rely on several other sources of data at various points in the empirical work; these are discussed in the data appendix.

Sample

Insurers were allowed to establish PPOs in California beginning in mid-1983, but they did not gain a substantial share of the private insurance market until after 1984. I therefore study changes in hospital behavior over the 1984-1988 period. The sample consists of all short-term acute care hospitals in the state of California which were operating from 1982-1988 and which have available inpatient discharge data and non-zero uncompensated care 
in 1984 and 1988. ${ }^{1}$ The basic sample is 398 hospitals. Table 1 presents the means of the data for 1984 and 1988 (where the data are time-varying). The means are weighted by total hospital admissions in 1988, as are all regressions, unless otherwise noted. ${ }^{2}$

\section{Measuring Market Competition}

I measure ex-ante competition with a "patient origin herfindahl", discussed in Zwanziger and Melnick (1988), which defines the hospital's market area by the locations from which it draws its patients. This index is created in two steps, using the discharge data (which reports the patient's zip code of residence) for 1982 for all privately insured patients. ${ }^{3}$ First, for each zip code in California, a herfindahl index is created by summing the squared market shares of each hospital which draws from that zip code. Second, a hospital-specific competition index is created by taking a weighted average of the herfindahls for each zip code from which the hospital draws, where the weights are the fraction of the hospital's patients from that zip code. That is, if hospitals draw their patients from "competitive" areas (zip codes where

'The latter restriction arises from the use of the log of the dependent variable in the uncompensated care regressions. It only excludes five very small hospitals from the sample.

${ }^{2}$ Since most of the dependent variables used (ie. cost per discharge) are defined at the patient level, hospitals with a large number of admissions will have more precisely measured values. The weight reflects this. The estimates are similar if the robust standard error correction of White (1978) is used instead.

${ }^{3}$ The PPO enabling legislation didn't take effect until 1983, so that this data should be free of their influence. This measure differs from that used by Zwanziger and Melnick, who allow the extent of competition to differ by type of service. However, they build their competition measure for all patients, whereas mine focuses only on private pay patients, which may be more appropriate for studying the influence of PPOs. 
patients go to a large number of different hospitals), then they are competitive hospitals. The construction of the herfindahl is discussed in more detail in the data appendix.

A potential disadvantage of this measure is that the market area definition is determined by patient choice in the pre-PPO era, which may be endogenous to hospital characteristics that are correlated with prices as well (such as reputation or specialization). This would lead to a biased coefficient on the herfindahl in a price regression. However, the regressions which will be run below relate the change in price to the herfindahl. Thus, any fixed differences between more and less ex-ante competitive markets will be differenced away. If price competition proceeds along the same dimensions as prior competition (as the discussion above suggested that it should), then this spurious factor which is correlated with market concentration can be taken as fixed, and the herfindahl will therefore be exogenous in the changes regression.

A direct implication of my claim that ex-post competition follows the same pattern as ex-ante competition is that the observed pattern of patient choice does not change after the arrival of PPOs. In fact, the pattern of choice does appear to be largely the same: the patient origin herfindahl created for 1988 is very highly correlated with that created for 1982 (correlation $=0.93$ ). Given that PPOs had organized such a large share of the privately insured population in Califormia by 1988, this fact implies that price shopping did not alter the pattern of patient choice in the short run, justifying the fixed effects assumption. 4

'Furthermore, the null hypothesis that the herfindahl is exogenous in the changes regressions can also be tested given an alternative measure of competition which is consistent, but less efficient, under this null hypothesis, and which is consistent under the alternative that the herfindahl is endogenous (Hausman, 1978). One such alternative measure is the number of other 
Regression Framework and Identification Issues

In the empirical work, I will run regressions of the form (for hospital "i"):

$$
\Delta \text { NPRICE }_{\mathrm{i}}=\alpha+\beta \mathrm{HERF}_{\mathrm{i}}+\Delta \mathrm{Z}_{\mathrm{il}} \pi+\epsilon_{\mathrm{il}}
$$

(1)

$\triangle N P R I C E_{i}$ is the change in net prices from 1984 to 1988 , the period during which PPOs arrived. I will also run similar regressions using hospital costs and uncompensated care as dependent variables. $\mathrm{HERF}_{\mathrm{i}}$ is patient origin herfindahl, as described above. $Z_{i t}$ are other hospital specific controls which are both time varying and time invariant. $\epsilon_{\mathrm{i}}$ is a white noise error.

As discussed above, this model only yields predictions about the relation between market concentration and changes in prices, costs, and uncompensated care, since more competitive hospital markets may differ from less competitive ones in a number of ways in the ex-ante equilibrium. The key assumption of this model is therefore that there were no other features of the California hospital market which changed during 1984-1988, and which were correlated with both competition and prices, costs, or uncompensated care. Ideally, this assumption could be tested by comparison to another sample of hospitals, where PPOs weren't present, over the same time period. This identification strategy would allow me to capture any underlying changes in the effect of competition in the absence of price shopping. However, data limitations for other states, as well as the rapid spread of PPOs over this

hospitals within a five mile radius of the hospital (unpublished data from the University of California at San Francisco). The five mile measure can be taken as exogenous to patient decisions in the short run, but it is less efficient because of the arbitrariness of the radius chosen, and because it does not capture pre-existing features of hospital markets which are relevant in determining hospital bargaining power vis-a-vis PPOs. Using this specification test, the exogeneity of the herfindahl cannot be rejected in any of the regressions below. 
period, make this impossible.

Instead, I use the set of California hospitals over an earlier period (1982-1984), before PPOs had a substantial market presence, to test for time invariant effects of competition on changes in prices, costs, and uncompensated care. While this does not control for contemporaneous shocks, it does control for any secular trends in prices which are correlated with market competition.s

I also control for other major changes in the hospital environment over the 1984-1988 period in an effort to isolate the impact of price competition. One important event was the introduction of Medicare's PPS in October, 1983. Before this time, hospitals were reimbursed by Medicare based on their reported patient care costs. Under PPS, hospitals are primarily paid based not on their own costs, but based on a regional/national average. As the program has been phased in, it has steadily decreased the average reimbursement to hospitals. My measure of the hospital-specific impact of PPS is the PPS "Bite", which measures the shortfall of reimbursement under PPS relative to historical costs, trended forward by average statewide cost inflation. The change in the Bite from 1984 to 1988 is multiplied by the

'This also helps to separate the effects of price competition, after the PPO enabling legislation of 1983, from the effects of continued growth of HMOs. While HMOs did grow rapidly over the 1984-1988 period, they grew equally fast over 1982-1984 as well, so that any effect which they had which was distinct from price competition should show up in this earlier era. Furthermore, most HMO enrollment in the state during the period of this study was in the Kaiser-Permanante HMO, which maintains its own hospitals (which are not included in this analysis).

${ }^{6}$ For studies of the impact of PPS on hospital behavior, see Cutler (1991), Staiger and Gaumer (1991), and Feder, Hadley, and Zuckerman (1987). The bite variable used here is similar to that used in those papers. The 1984 bite attempts to account for the fact that a number of hospitals were not yet on the PPS system; however, the 1982-84 regression results below suggest that I may 
historical (1982) Medicare share of revenues to create " $\Delta B$ BiteShare", capturing the importance of this cutback in Medicare reimbursement to the hospitals total revenues. The calculation of this index is described in the data appendix. ${ }^{7}$

In early 1983, California also initiated selective contracting for its Medicaid program ("Medi-Cal"), which previously paid hospitals based on an average of their own costs and statewide inflation. Under selective contracting, the state negotiated with providers in each of a number of areas in the state to become the exclusive Medi-Cal provider for that area. ${ }^{8}$ Previous researchers have used the fraction of the hospital's revenues which were from Medi-Cal in 1982 as a proxy for the potential financial impact of selective contracting. Absent a better measure, I use this index as well. To the extent that the state of California had more power in negotiating its MediCal contracts in more competitive areas, my competition measure may capture some of the effects of selective contracting. Below, I will test more directly the hypothesis that the competition index is measuring the effect of increased competition among private payers, and not the effects of Medi-Cal selective contracting.

have mismeasured the bite for the first year of PPS.

${ }^{7}$ An alternative story which has been suggested to me to explain the arrival of price competition after 1984 is not that it was due to the relaxing of regulatory constraints on PPOs, but rather that PPS ushered in an era of price competition, and PPO growth was an endogenous response to this new era. However, the root cause of the arrival of price competition is irrelevant for interpreting the results below. The key point is that price competition could not take place without PPOs (or something like them) as a facilitating mechanism, and that it is the need for PPOs to attract local enrollees which gives rise to the correlation between ex-ante hospital market share and ex-post hospital market power in negotiating prices.

${ }^{8}$ For analyses of the impact of selective contracting, see Johns (1989), Zwanziger and Melnick (1988), and Robinson and Phibbs (1989). 
While the regressions are estimated for the change in prices, costs, and uncompensated care over the 1984-1988 period, I also include a set of time invariant controls to capture aspects of the hospital and its market area which may affect these changes. I include hospital level controls for ownership (dummies for public, for-profit, and religiously affiliated non-profit hospitals), teaching status (intern/bed ratio), and scale of operations (the log of the number of beds). In this way, I rule out general changes in hospital behavior which are correlated with their time invariant characteristics, such as changes in pricing strategies by for-profit hospitals.

Finally, the regression also includes a set of controls for the area in which hospital i resides: a central city dummy, a rural dummy, and (in some specifications) a set of dummies for the 14 "Health Service Areas" (HSAs) designated by the state of California.' In this way, I can control for areaspecific shocks over this period which may be correlated with both competition and the dependent variable of interest, such as shifts in the distribution of the uninsured population which may confound the uncompensated care results. This within area estimation is made possible by the fact that the herfindahl is a hospital based measure, so that it varies substantially within HSAs. ${ }^{10}$

'The HSAs divide the state into fairly equal areas, with between $2 \%$ and $8 \%$ of the hospital beds in each, except for the Los Angeles HSA, which contains $36 \%$ of the beds. The results are the same when I control separately for central city Los Angeles.

${ }^{10}$ While these controls do absorb about one-half of the variation in my competition measure, I do not feel that this is legitimate variation for identification, due to changes in the hospital environment across these broad areas during this period (such as the spread of AIDS in Los Angeles and San Francisco). 


\section{PART III: EX-ANTE HOSPITAL COMPETITION AND EX-POST PRICE SHOPPING}

The purpose of this Part is to test the claim that price shopping was the most effective in the most ex-ante competitive markets. Ideally, the dependent variable for testing this prediction would be a weighted average of the discounts given, and net prices charged, to the set of hospital PPO customers. Unfortunately, hospitals do not report the discount percentage offered to PPOs or the net price charged, but rather only the total dollars given in discounts to, and the total revenues earned from, non-government payers. As an approximation to the discount percentage, I use discounts over total gross non-government revenues. For net price, I use the net revenues (total minus discounts) from non-government payers, over total days of care to these payers, or net average revenue per day."

Column (1) of Table 2 presents estimates from a regression of the 1984-1988 change in discounts over revenues on the patient origin herfindahl and the set of controls which will be used throughout this analysis. The competition measure has a significant effect on discounts in the expected direction: the negative coefficient indicates increased discounts in more competitive areas. This estimate implies that a one standard deviation decrease in the herfindahl would lead to an increase in discounts of about $1.6 \%$ of nongovernment revenues. That is, the average hospital in Los Angeles county saw a rise in discounts over inpatient revenues of $4 \%$ relative to the average hospital in Northern California due to the increased level of market competition.

${ }^{11} I$ do not identify here the effect of competition on the actual price charged, but rather the effect on average revenues. This may confound the facts that both a lower price is being charged and that it is being charged to more patients; since PPOs can offer the best deal to potential enrollees in more competitive markets, enrollment should be the highest there. 
Discounts grew more slowly at public, for-profit, and teaching hospitals than at non-profits, and faster in central cities. Furthermore, hospitals which were hit hardest by the government cost control programs saw the smallest increase in discounts. A rise in $\Delta B$ iteShare indicates decreased reimbursement under PPS (relative to cost-based reimbursement), so that the negative coefficient implies that hospitals that saw the greatest fall in Medicare price under PPS increased discounts the least. A larger Medi-Cal share indicates a bigger effect of selective contracting, so that more Medi-Cal pressure led to lower discounts as well. These findings may imply that PPOs were able to garner the biggest gains where there were the most excess rents; hospitals which were burdened by other forms of cost control could not afford to offer sizeable discounts.

Column (2) adds a set of 14 HSA dummies. They are highly (jointly) significant, and serve to increase the coefficient on the competition measure substantially, so that the average hospital in LA is now found to have increased discounts over inpatient revenues by $7.2 \%$ more than the average hospital in Northern California. The strong predictive power of the competition measure within fairly narrow areas of the state is striking.

One problem with these regressions is the potential endogeneity of the gross price charged to traditionally insured patients. If hospitals are able to shift the burden of their PPO discounts to their commercially insured and Blue Cross patients, then increased discounts may not proxy for lower net prices. Thus, in column (3) of Table 2, I use the change in the log of net average non-government revenues per day as the dependent variable; the regression includes the HSA effects, which are once again highly (jointly) significant. There is a significant (at the $7 \%$ level) fall in net average revenues, which 
indicates that the cost is not simply being shifted to other private payers. ${ }^{12}$

If either patient severity or treatment intensity (other than length of stay) were falling in more competitive areas, then it could bias the net revenue per day results downwards. I attempt to control for these factors in column (4) of Table 2. I proxy for changes in patient severity by using the change in the "case mix index" for all private pay patients, which assigns severity weights to each patient's primary diagnosis, and then tabulates the average severity weight by hospital (see data appendix). I measure changes in treatment intensity by the log change in the average number of procedures performed during a private pay patient stay, tabulated by hospital from the discharge abstract data. These controls do not enter significantly, nor do they affect the coefficient on the herfindabl.

An important component of my argument is that price competition was only possible once PPOs had been introduced as a facilitating mechanism. A testable implication of this claim is that there should not have been rising discounts and falling prices in more competitive markets before 1984. Column (5) of Table 2 presents the discount regression over the 1982-1984 period, and shows that there in fact is no correlation between market competition and discounts over this period. ${ }^{13}$ Thus, there does not appear to have been a

${ }^{12}$ These findings are similar to those of Dranove et al. (1992). This lack of shifting is perhaps unsurprising given the virtual disappearance of traditional insurance over this period. The data in Melnick, Zwanziger and Bradley (1989) show that, by 1988, over two-thirds of the state's population was covered by some sort of negotiated arrangement with health care providers, while tabulations from the 1989 March Current Population Survey reveal that about $20 \%$ of the population lacked insurance. The remaining base of traditionally insured patients may simply not have been broad enough to bear the costs of PPO discounts.

${ }^{13}$ The coefficients are much smaller than in column (3) since discount growth is much lower over the earlier period. The result is similar if the specification check is done on net average revenues per day instead. The 
trend towards falling prices in more competitive markets before the arrival of PPOs.

These results provide fairly strong evidence that net revenues were falling in more ex-ante competitive markets, which suggests that the move to price competition had the greatest effect there. Given this relationship, the remainder of the paper is devoted to estimating the effect of price competition on two key indicators of hospital behavior: costs and uncompensated care.

Before doing so, however, I pause to consider an alternative explanation for my findings, which is the effects Medi-Cal's selective contracting program. As described above, this program is similar to a PPO for Medi-Cal patients, so it may also have had its greatest impact in the most competitive hospital markets. I test for the effect of market structure on MediCal pricing in column (6) of Table 2, where I use as a dependent variable the log change in the Medi-Cal net average revenues, which is defined analogously to private average net revenues. In fact, Medi-Cal prices do not seem to be falling significantly in the most ex-ante competitive markets. Thus, the effects of market competition on costs and on uncompensated care can be taken to reflect the change in the nature of private price setting and not that of government price setting. ${ }^{14}$

significant positive coefficient for $\Delta B$ iteShare is troubling, and suggests that I may have mismeasured the effects of PPS in its first year; the herfindahl coefficient is similar if $\Delta$ BiteShare is excluded.

${ }^{14} \mathrm{~A}$ similar hypothesis could be developed for the relation between Medicare net revenues and market competition: if costs where highest in the most ex-ante competitive markets, Medicare could have the biggest influence there. To the extent that $\triangle$ BiteShare misspecifies the effect of PPS, the herfindahl may be picking up this effect. However, a similar regression using change in Medicare net price as a dependent variable reveals no relation to the herfindahl. 


\section{PART IV: PRICE COMPETITION AND HOSPITAL COSTS}

In the context of health care market reform, the terms prices and costs are used almost interchangeably. Yet, hospital prices are in fact the sum of two components: costs and markups. It is not obvious ex-ante that increased price competition, which leads to lower prices, will result in lower hospital costs as well. In fact, under the quality competition model, with quality competition persisting into the price shopping era, costs should not be expected to fall; under the Satterthwaite model, the implication of price shopping for costs is uncertain. The only evidence on this point is the study of Zwanziger and Melnick (1988), who examined California hospital data for the mid-1980s and found a significant reduction in hospital costs in areas with a higher degree of provider competition, which they attribute to the advent of provider contracting with hospitals.

In Table 3, I adopt a framework similar to that of Zwanziger and Melnick, as I examine the change in log operating expenses over the 19841988 period. The specification is the same as that of the previous tables, with two additional controls: the change in case mix index for all patients in the hospital, to control for severity differences which may affect costs; and the change in log discharges for the hospital, to control for changes in the scale

of operation. ${ }^{15}$ The first column of Table 3 confirms the findings of Zwanziger and Melnick. Costs did rise more slowly in more competitive areas over the 1984-1988 period, with costs rising $3.6 \%$ faster in Northern California than in LA due to a lack of competitive pressure. The Medicare

${ }^{15}$ These two regressors are potentially endogenous. However, the results without the case mix control are very similar. If I normalize expenses by discharges (imposing a coefficient on change in log discharges of 1), the coefficient on the herfindahl is insignificant. It is very similar to the reported coefficient once the HSA dummies are included, however. 
PPS control indicates a strong and significant effect on hospital costs as well, with approximately $70 \%$ of the shortfall in reimbursement under PPS being absorbed in lower costs; this confirms the earlier finding of PPS's cost effects in Feder, Hadley and Zuckerman (1987). The Medi-Cal control is also negative and significant, indicating that selective contracting led to lower costs; the coefficient is similar to that of Robinson and Phibbs (1989). The other controls do not add much explanatory power, except for the case-mix control, which indicates that costs are higher in hospitals with a more severely ill patient mix. ${ }^{16}$

In column (2), I add the set of 14 HSA dummies. The effect on the herfindahl coefficient is dramatic; it is now negative and insignificant. This indicates that costs actually rose in more competitive areas, with a one standard deviation increase in the herfindahl leading to a $0.6 \%$ increase in costs. This effect of including the area specific controls suggests that locational shocks which were correlated with market competitiveness were driving the cost findings of column (1). There is no effect of adding the HSA dummies on the PPS measure, and the coefficient on the Medi-Cal share rise. In the third column of the table, I reestimate this specification over the 19821984 period, and it reveals that there was no preexisting correlation between market structure and changes in hospital costs. ${ }^{17}$

The contrast between the effects on costs of Medicare's PPS and of

${ }^{16}$ One problem is that $\Delta B i t e S h a r e$ is a function of lagged (1982) costs; if there is any serially correlated measurement error in expenses, this will bias the estimate of the PPS variable. I have tried instrumenting $\triangle B$ iteShare by the 1982 Medicare share, which is the component of this variable which is exogenous to expenses; it does not affect the results.

17The case mix index change is omitted because this index cannot be calculated for 1982. The large coefficient on $\Delta$ BiteShare in the 1982-1984 regressions once again implies that this index mismeasures the cost pressure on hospitals in the first year of PPS. 
market competition is striking. While over two-thirds of the cutbacks under PPS were absorbed in lower hospital costs over the 1984-1988 period, market competition was found to have no significant effect on costs. The difference in the effect of these two means of "cost control" on hospital costs can be traced to their incentives for patient treatment intensity (ie. length of stay) per admission, which is the key factor behind hospital cost increases. Medicare reimburses hospitals by a fixed price per admission strategy, whereby hospitals receive a fixed lump sum payment for an admission of a given severity. As discussed in Cutler (1991), since hospitals bear the full marginal cost of additional treatment quality, this introduces strong incentives to reduce intensity under a wide variety of models of hospital behavior. Cutler also provides evidence that increases in Medicare cost pressure are associated with falls in the treatment intensity of the elderly. ${ }^{18}$

Price competition, on the other hand, did not introduce strong incentives for reductions in patient treatment intensity, for two reasons. First, PPOs generally reimburse by discounts off of usual charges. Since hospitals are still being paid on the margin for additional quality, the incentive to reduce costs by cutting quality is much weaker. Second, as discussed above, to the extent that shopping on the basis of treatment quality existed in the ex-ante equilibrium, such shopping continued after the arrival of PPOs. Thus, hospitals who cut their treatment intensity in response to price pressure could lose patients as a result. In fact, the quality elasticity for PPO patients may have been much higher than that for Medicare patients, since these organizations have more scope for evaluating treatment quality from a large number of hospitals than do individual Medicare enrollees.

${ }^{18}$ In Gruber (1991), I replicate these regressions for California, and find similar strong reductions in Medicare treatment intensity where the Medicare "bite" is largest. 
A more direct test of this supposition would be to ask whether increases in competition are associated with changes in the treatment intensity of PPO patients, just as increased PPS pressure led to a fall in intensity for the elderly. In the remainder of Table 3, I model the relation between PPO treatment intensity and market competition in 1988. This levels regression necessarily differs from the changes specification used elsewhere, since there is no data on PPO treatment in 1984; the hypothesis here is not about changes due to the arrival of PPOs, but rather about differences due to the contemporaneous level of competitive pressure. The problem which this raises, however, is that I am not able to purge the equation of time invariant differences between more competitive and less competitive markets, as I do in the changes specification.

In order to control for systematic differences across markets in treatment styles, I use as the dependent variable the difference between the treatment intensity of PPO patients and the treatment intensity of the traditionally insured. That is, rather than removing a fixed effect for market structure, I remove the effect of market structure on treatment intensity for this control group, : rd ask: do hospitals which face more competitive pressure . treat PPO patier ts worse than their traditionally insured counterparts?

Treatment intensity is measured along two dimensionsi length of stay and average charges per admission. I have tabulated average intensity per hospital from the "HMO/Prepaid Health Plan payer field for PPOs," and for the fields for "Commercial Insurance" and "Blue Cross/Blue. Shield" for

${ }^{19}$ This is the field into which hospitals were supposed to classify PPO patients during the period of my study (personal communication, California Office of Statewide Health Planning and Development). By' 1988, PPO enrollment was between 3 and 4 times as large as HMO enrollment in California, excluding enrollment in the Kaiser-Permanante HMO. Thus, in 1988, the mean of treatment intensity for this field should be a reasonable proxy for PPO patient treatment. 
the traditionally insured. All treatment intensity measures are normalized for case severity using the California severity index described in the data appendix. Since PPO and/or traditionally insured admissions are very low at some hospitals, I weight the regressions by a function of the hospital's number of admissions in the HMO/PHP category and those in the traditionally insured categories. ${ }^{20}$

Columns (4) and (5) regress the difference in log treatment intensity of the usual set of covariates. The results are consistent with the conclusions above: PPO treatment intensity is no different than that for the traditionally insured, in more competitive relative to less competitive markets. PPO length of stay is somewhat higher, and average charges somewhat lower, where the herfindahl is lowest, but neither estimate is as large as its standard error. One problem with estimating the relative treatment intensity of PPO patients, however, is selection bias. If the individuals in this payer field are systematically less healthy in more competitive areas (relative to the traditionally insured), then the herfindahl coefficient will be biased against a findung of reduced intensity. This may be irue, for example, if PPOs in more compejtitive areas have the most effective pre-admission res ;ews of potential hospit;alizations, so that they keep the least sick cases out of the hospital. Of course, if selection bias serves to move patients across the 470 "Diagnostic

" Related Group" (DRG) classifications used in my severity index, then it will be captured by the severity adjustment to the intensity measures; only if there are within-DíR severity differences will selection remain a problem.

${ }^{20}$ More specifically, if PPO admissions are $n_{1}$, and traditionally insured admissions are $n_{2}$, I weight by: $n_{1}^{*} n_{2}$

$$
\left(n_{1}+n_{2}\right)
$$

This is appriopriate if the variance of each group's average treatment intensity is proportional to one over the number of admissions in that group, and the two groups' averages are independent. 
However, if the severity of PPO patients is relatively greater within DRG, then it will most likely be greater across DRGs as well. In column (6), I therefore test for selection by using as the dependent variable the difference in the case mix index between PPO patients and the traditionally insured. This difference is not significantly related to the herfindahl, suggesting that selection is not an important problem.

Thus, the striking differences in the effects of these two forms of cost containment on costs may be largely due to their effects (or lack thereof) on patient treatment intensity. This implies that forcing hospitals to bear the full marginal cost of an additional unit of treatment intensity (as PPS did) offered more incentive for intensity decreases than did lowering the net price that hospitals received (while leaving unchanged the demand for treatment quality).

If costs are not falling in response to competitive pressure, then the reduction in average revenues will be coming out of hospital markups per patient. $^{21}$ In the next section, I focus on the effect of market competition on an important hospital activity which is financed out of these markups: care to the uninsured.

\section{PART V: COMPETITIVE PRESSURE AND HOSPITAL UNCOMPENSATED CARE}

Hospitals are an important source of care for the uninsured: hospital . uncompensated charges totalled $\$ 15$ billion in 1989 , which was over $6 \%$ of

${ }^{21}$ Of course, if hospitals which gave larger discounts gained PPO patients, then the fall in markups per patient may have been offset. However, there is no relation between market competition and changes in the total number of private hospital admissions (traditionally insured plus HMO/PHP). This suggests that PPOs are not actually causing net patient movement, but are instead inducing lower hospital prices through the threat of such movement. 
total gross patient revenues. ${ }^{2}$ Traditionally, hospitals have used higher charges to private patients to cross-subsidize their care to the uninsured. If competitive pressure lowers hospital markups, they may lower the amount of uncompensated care that hospitals can afford to provide.

Increased price shopping may not lead to reduced unconipensated care, however, if hospitals are either unwilling or unable to adjust this form of charity. Under the Emergency Medical Treatment and Active Labor Law of 1986, hospitals which receive Medicare funding must at least stabilize any patient brought to their emergency room (Public Citizen, 1991). Hospitals which received construction funds through the Hill-Burton program are also required to provide a minimum level of charity care tied to the level of those funds. To the extent that these regulatory requirements are binding, it will limit the ability of hospitals to reduce their uncompensated care; the response of charity to competitive pressure is an empirical question.

I examine the effect of market competition on uncompensated care in Table 4. The dependent variable is the change in log hospital uncompensated charges, which is the sum of "free care" and "bad debt". I also add four covariates to the basic regression framework: the change in log gross patient revenues, the change in the percent uninsured in the SMSA, the log of the median income in the hospital's area, and a dummy for sole community hospitals. The first controls for the scale of hospital operations. The second proxies for changes in "demand" for uncompensated care by the uninsured; area income will also capture demand if individuals will be less likely to pay their bills in less wealthy areas. The last is included to capture the fact that

${ }^{2}$ Aggregate uncompensated care figures from unpublished American Hospital Association data. Both Saywell et al. (1989) and Weissman et al. (1991) estimate that approximately $2 / 3$ of uncompensated charges are to the uninsured; the remainder arise from insured patients who do not pay some portion of their bills. 
hospitals which are the only source of uncompensated care in an area may be unable to cut back on their care. ${ }^{23}$

The first column of Table 4 provides strong evidence that hospitals in more competitive areas reduced their uncompensated care. The herfindahl enters significantly, and indicates that a one standard deviation increase in competition led to a $7.8 \%$ fall in uncompensated care. In the second column, I add the set of HSA dummies, and the coefficient rises, although the level of significance is the same. The robustness of this finding to the inclusion of area specific effects suggests that it is not driven solely by changes in the distribution of the uninsured population which are not captured by my demand controls.

$\Delta$ BiteShare actually enters the regression positively, although it is insignificant in both cases. The fact that PPS pressure did not lead to less uncompensated care corroborates the conclusion above that most of the impact of Medicare payment reductions was absorbed through reduced expenses. While the per cent uninsured in the area does enter positively in the first column, it is insignificant. The level of area income enters positively, suggesting that uncompensated care rose in wealthier areas, even within HSA. This may be the result of a negative correlation between the change in area income and the level of income; or it could be that median income is an incorrect proxy for demand. Public and religiously-affiliated hospitals are

${ }^{23}$ None of the results reported below is affected by the use of uncompensated care costs in place of charges. The coefficient on the scale control is very close to one, and normalizing the dependent variable yields identical results. The data on insurance status are from the March CPS for 1982-1989; see the data appendix. Median area income is calculated using zip code level income data from Rezide (1985), assigned to hospitals by the zip codes from which they draw their patients. Sole community hospitals are those that are the only source of inpatient services in a geographic area, as defined by Medicare. 
found to deliver more uncompensated care, and teaching hospitals deliver less. The Medi-Cal share enters with a sizeable positive coefficient, which is the opposite of what would be expected if Medi-Cal selective contracting squeezed hospital markups. This variable, which is also a measure of traditional care to the poor, may be proxying for unobservables correlated with the hospital's propensity to deliver uncompensated care.

The model in Table 4 will not be identified if other factors correlated with market competition affects changes in the delivery of uncompensated care. For example, if there is charity "crowding out" in more competitive areas, because hospitals know that they have more neighbors to provide this care, it will induce a spurious negative correlation between competition and uncompensated care (Frank and Salkever, 1991). Once again, I assess this potential bias by looking at the same set of hospitals in an earlier era. Column (3) reveals that there is no pre-existing relationship between competition and changes in uncompensated care.

Taken together with the earlier findings, these results suggest that the introduction of price competition reduced the markups available to hospitals, and that this led to a fall in uncompensated care. Given this conclusion, a natural parameter of policy interest is the extent to which falling markups led to reduced care to the uninsured, or the income elasticity of uncompensated care. In column (4) of Table 4, I regress the change in uncompensated care on the change in discounts to private payers, along with the set of controls from the previous columns. ${ }^{24}$ There is a strong negative relationship between the change in discounts and the change in uncompensated care; an increase in discounts of $1 \%$ of revenues is found to lead to a $3.35 \%$ fall in uncompensated

${ }^{24} \mathrm{I}$ replace the change in discounts over inpatient non-government revenues used earlier with the change in discounts over total revenues, in order to gauge the potential impact on total hospital income of a cutback by private payers only. 
care. Over 1984-1988, uncompensated care averaged 6.9\% of hospital revenues; this implies that a one dollar increase in discounts led to a fall in uncompensated care of 23 cents.

This OLS estimate, however, is contaminated by the fact that discounts are simultaneously chosen along with uncompensated care. In fact, there is reason to believe that this would impart a positive bias to the discounts coefficient; if hospitals finance increases in uncompensated care by raising charges to insured patients, and PPOs negotiate over net prices, then PPOS will demand a larger discount where there is more uncompensated care (higher charges). However, if the only way in which market structure affects changes in uncompensated care is through competitive pressure, then the herfindahl serves as a valid instrument for estimating the income elasticity of uncompensated care. To do so, I use the regression in Table 2 , relating the growth in discounts to market competition, as a first stage regression. In the second stage, I relate the change in uncompensated care to the change in discounts over revenues, instrumented by the herfindahl. This structural regression estimates the effect of an exogenous decrease in hospital income on hospital uncompensated care.

Column (5) runs the two stage least squares version of the income elasticity equation, where discounts are instrumented by market competitiveness. The coefficient does rise, implying that the positive bias discussed above may have been important; while the standard error rises by even more, the estimate is significant. A one dollar increase in discounts is now associated with a 53 cent reduction in uncompensated care. This sizeable elasticity implies that the $4.7 \%$ average rise in discounts over revenues during this era led to a $36 \%$ fall in the amount of uncompensated care delivered, relative to its expected value.

How are Hospitals Adjusting Their Care to the Uninsured? 
The estimates of Table 4 suggest a large reduction in uncompensated care, relative to its expected level, in response to competitive pressure. In order to understand the welfare implications of cutbacks in uncompensated care, however, it is necessary to identify the means through which hospitals are adjusting their care to the uninsured. Are hospitals seeing fewer uninsured patients? Or are they seeing the same number, but cutting the intensity of treatment?

In Table 5, I estimate the effect of competitive pressure on inpatient utilization of the uninsured, which is tabulated from the discharge data abstracts for patients whose expected source of payment is "Self-Pay". 2s In the first column, the dependent variable is the change in log admissions to the uninsured. The basic specification is the same as that of Table 4, although the scale control is now the change in log private admissions. In contrast to the reduced form model in the second column of Table 4, however, the herfindahl is wrong-signed and completely insignificant. Given the earlier estimates of a sizeable reduction in uncompensated care, this is a disturbing result.

If hospitals were unable to tum away the uninsured; however, they may have reacted solely by adjusting treatment of the uninsured who were admitted. This is examined in the second and third columns of Table 5, for the two measures of treatment intensity used earlier, tabulated for the uninsured and normalized for case severity. For length of stay, the herfindahl also enters negatively, while for average charges there is evidence of reduced care to the uninsured in more competitive areas. However, neither estimate is significant.

\footnotetext{
${ }^{25}$ I do not use the payer field for "Medically Indigent", because hospitals may be reimbursed by the county for some portion of their care to those individuals classified as medically indigent under Section 17000 of the California Statutes. The results are very similar if these individuals are included.
} 
These results do not offer much insight into how the reduction in uncompensated care was carried out at the hospitals which were subject to competitive pressure. However, there are two important problems with these data for analyzing this question. First, the payer source (self-pay) is that which is expected at the time of admission, and, if the ultimate source of payment is unknown at that time, there may be misclassification error. Discharge abstracts, which are turned in six months after discharge, are often not updated to reflect changes in payer status. While there is no strong prior about the bias imparted by this misclassification, it does signal the potential for important measurement error problems. Second, this data source ignores outpatient care to the uninsured, a group which is disproportionately cared for in an outpatient setting. In their study of New York state's subsidy for hospital uncompensated care, Thorpe and Spencer (1991, fn 17) report that "the bulk" of the response of uncompensated care occurred on the outpatient margin. Their results suggest the value of investigating the response of outpatient uncompensated care to increases in competitive pressure.

A detailed study of outpatient care to the uninsured is limited by the fact that regulators do not collect patient level data on outpatient care. However, the hospital disclosure report does contain data on the aggregate level of utilization of hospital services, including emergency room visits and gross revenues. In two recent profiles of emergency room utilization, over two-thirds of the visits made to the emergency room were by the uninsured (Bindman et al., 1991; Baker et al., 1991). Thus, hospital actions to decrease access of the uninsured to emergency rooms should be reflected in aggregate utilization statistics. ${ }^{26}$ Furthermore, if hospitals desire to cut back on care

${ }^{26}$ In fact, the state of California has seen a wave of trauma emergency room closings since the mid-1980s; 55 hospitals which reported offering access to a trauma treatment emergency room in 1984 reported no such access in 1988. Probit regressions of closings on the herfindahl yielded a negative, but 
to the uninsured where the need is least urgent, emergency rooms, ironically, could absorb much of the adjustment. Grumbach et al. (1991) found that only $13 \%$ of patients surveyed while waiting for care at a large public hospital emergency room had conditions that were definitely clinically appropriate for emergency department services. ${ }^{27}$

In the remainder of Table 5, I examine changes in the scope of operation of emergency rooms across hospitals over the 1984-1988 period. The dependent variable in the fourth column is the change in the log number of emergency room visits. There is a sizeable fall in emergency room visits in more competitive areas, with a one standard deviation increase in the herfindahl being associated with a $5.5 \%$ fall in visits (significant at $11 \%$ level). This implies that emergency room visits fell by $14 \%$ in LA relative to Northern California, due to increased competitive pressure; the inclusion of HSA effects should control for gross regional changes in health conditions which would bias this result.

In column (5) the dependent variable is the change in log gross emergency room revenues; the change in log total gross outpatient revenues is included on the right hand side in order to control for general shifts to outpatient utilization and/or changes in outpatient pricing. Once again, there is a sizeable (statistically significant) fall in emergency room utilization in more competitive areas. In the final column, I use the structural specification

insignificant coefficient; similarly, hours of emergency room staffing fell (insignificantly) in more competitive areas.

${ }^{27}$ This figure is an understatement, since the study excluded those with the most severe conditions, who did not wait for care. This most severe group represented $16 \%$ of emergency room visits, so that the overall fraction of definitely clinically appropriate visits is approximately $27 \%$. This is consistent with the figure of $43 \%$ reported by Baker et al. (1991), who used a more expansive definition of clinical appropriateness. 
of column (6) of Table 4, where the change in discounts over revenues is instrumented by the herfindahl. A one dollar increase in discounts is found to lead to a fall in emergency room revenues of 15 cents. While this result can only account for (at most) one-third of the fall in uncompensated care estimated in Table 4, it does suggest that a substantial portion of the adjustment of uncompensated care was happening on the outpatient margin. The welfare implications of this fall in care to the uninsured are considered in the conclusions. ${ }^{28}$

\section{PART VI: CONCLUSIONS}

From 1950-1980, health care costs doubled as a fraction of GNP, and the systems of "cost-plus" reimbursement by the public sector and indemnity insurance in the private sector were seen as two of the primary culprits. As a response, the structure of both private and public insurance has been radirally transformed over the past decade. At one extreme is the regulatory approach employed by Medicare, which sets fixed prices per admission, and several states, which regulate the overall level of hospital cost increase. Price shopping in medical markets, facilitated by the use of Preferred Provider Organizations, represents the vanguard of an alternative competitive approach. In this paper, I have examined the effects of price shopping across hospital markets in California. I argued that ex-ante actual competition was a good

\footnotetext{
${ }^{28} \mathrm{~A}$ further explanation for the discrepancy between the uncompensated care results and the inpatient utilization results is that hospitals may have responded to competitive pressure by collecting more of their unpaid debts. This would yield reduced dollars of uncompensated care with no reduced units of care to the uninsured. The welfare implications of such a policy are unclear, however, and depend on the income distribution of the individuals from whom the increased bills are being collected. I am unable to investigate this empirically, due to the fungibility of the bad debt and charity care categories as measures of uncompensated care.
} 
proxy for ex-post price competition due to the need for PPOs to attract enrollees, and I found that net revenues did fall the most in the most ex-ante competitive markets.

A key consideration, however, is the means by which hospitals adjusted to this increased competitive pressure. Roughly speaking, hospital prices are the sum of two components, costs and markups, and the channel through which price shopping will lead to reduced net revenues is unclear ex ante. I have provided evidence that increased competitive pressure in Califormia over the 1984-1988 period led to reduced hospital markups, with little effect on hospitals costs. This fall in markups was found to have led to less care for the uninsured, with each dollar in increased discounts to private payers leading to a 50 cent fall in uncompensated care. This finding should be interpreted cautiously, give my inability to find a similar response in inpatient care of the uninsured; although some preliminary results suggested that outpatient care may have borne much of the adjustment.

The finding that price shopping did not lead to a fall in hospital costs highlights an important limitation of the managed competition strategy. Recent research on medical cost inflation has suggested that technological advance is the driving force behind cost increases (Weisbrod, 1991; Newhouse, 1992). Long run cost control strategies may therefore necessitate retarding the development of cost increasing, but potentially quality enhancing, technologies. In the discussion of Part I, I suggested that, since they must sell themselves to potential enrollees, organizations such as PPOs are essentially aggregations of individual preferences. Thus, until individuals are willing to make the sort of tradeoffs between quality and costs which are necessary, managed competition cannot effectively control medical cost inflation. If society feels that individuals are not capable of effectively making these choices, some form of government intervention may be required. On the other hand, there may be no better metric of which quality increases justify their cost than 
individuals' willingness to pay for them. ${ }^{29}$

A complete welfare analysis of managed competition also requires answering an important question raised by this study: what was the implication of price competition for the health of the uninsured? Over the 1984-1988 period, hospital uncompensated care (as a fraction of revenues) actually rose on average. At the same time, however, the uninsured population was growing, and the underlying health distribution of this population may have been deteriorating as well. ${ }^{30}$ The net change in services per uninsured person (of a given health level) is unclear, and depends on the extent to which the uninsured in competitive areas had access to hospitals in nearby noncompetitive areas. Furthermore, if the reduction in uncompensated care simply resulted in reduced "excess" utilization by the uninsured, then there may not have been important consequences for the health of this group.

Some evidence on these points is provided by a recent study of a public hospital closing in Northern California (Bindman et al., 1990). The authors found that uninsured patients saw a fall in their access to care when this local provider closed. As a result, there was a decrease in perceived health and an increase in reported pain. This suggests that reducing local hospital access for the uninsured in competitive areas may have had real health consequences.

Ultimately, reduced markups may leave private hospitals unable to support their care to the uninsured. If an increased level of resources are

${ }^{29}$ That is, there are no regulations against individuals willingness to pay more for higher quality consumer durables. However, there may be an important public goods aspect to medical technology which justifies government intervention: once such a technology is developed, it may be difficult, or perhaps even morally unacceptable, to exclude any individual from using that technology regardless of their insurance status.

${ }^{30}$ For example, due to the AIDS epidemic during these years. 
devoted to the uninsured at public hospitals, then this population may see little net reduction in their level of care. Furthermore, the members of the PPOs, which formerly supported care of the uninsured through the implicit taxation of cost-shifting, may now be forced to support this care through the explicit taxation necessary to support the work of public hospitals. But, if public hospitals get overcrowded, or it is not feasible to raise taxes to support their activities, then the uninsured will get less care, and PPO members will end up paying less. More research is needed into the question of what is happening to the quantity and quality of care to the uninsured, and their health outcomes, in California (and elsewhere) as competitive pressure increases. Similarly, more insight into the distributional aspects of alternative financing mechanisms for care to the uninsured (ie. cost-shifting versus local taxes) would help economists to assess the social costs of private sector cost containment.

Finally, it would be interesting to examine the other activities which are financed out of hospital markups. A better understanding of the objectives of (primarily non-profit) hospitals could provide some useful insight into the uses of hospital markups, and whether there are important welfare losses attached to their reduction from competitive pressure. 


\section{DATA APPENDIX}

\section{A) Measuring Ex-Ante Market Competition - Patient Origin Herfindahl}

The patient origin herfindahl is calculated by creating a herfindahl index for each zip code in the state, then taking a weighted average of the index for each zip code from which the hospital draws, where the weights are the share of the hospital's patients from that zip code. If we represent the distribution of hospital patients across zip codes as:

Hospital/ $\mathrm{H}_{1} \mathrm{H}_{2} \ldots \ldots \mathrm{H}_{\mathrm{h}}$. Total Zip Code

\begin{tabular}{|c|c|c|}
\hline$Z_{1}$ & $\dot{\lambda}_{11}$ & $\lambda_{12} \ldots \ldots \lambda_{1 k}$ \\
\hline $\mathrm{Z}_{2}$ & $\lambda_{21}$ & $\lambda_{2} \ldots \ldots \lambda_{z_{n}}$ \\
\hline
\end{tabular}

Total $\quad \mathrm{H}_{\mathrm{TI}} \mathrm{H}_{\mathrm{T} 2} \quad \mathbf{H}_{\mathrm{Th}}$

where: $\lambda_{i j}$ is the number of patients from zip code $i$ that go to hospital $j$

$Z_{\pi}$ is the total number of patients residing in zip code $i$

$H_{T j}$ is the total number of patients who go to hospital $j$

Then the Patient Origin Herfindahl for hospital $\mathrm{H}_{1}$ would be calculated as:

$$
\sum_{i=1}^{z} \frac{\lambda_{i l}}{H_{\pi}}\left\{\sum_{j=1}^{n}\left(\frac{\lambda_{i v}}{Z_{i T}}\right)^{2}\right\}
$$

This measure is calculated using the Hospital Discharge Dataset for 1982.

\section{B) California Private Payer Case Mix Index}

Treatment intensity has generally been normalized in past work by the standard Medicare Case Mix Index, as reported in ProPAC (1991). However, this case mix index is calculated primarily based on the elderly, and may be inappropriate for use in studying treatment of PPO patients and the uninsured. 
Therefore, I have calculated by own case mix index, based on all private pay admissions to California hospitals in 1984.' I do so by first tabulating the average cost by DRG, where cost is charges times the hospitals cost/charge ratio. ${ }^{2}$ I then remove any cases which are more than three standard deviations from the mean for that DRG (as is done in calculating the Medicare index). I tabulate the average costs over all DRGs, and assign a weight to each DRG by its average cost over the overall average cost. The correlation between this index and the Medicare index is 0.87 .

\section{C) Medicare PPS "Bite"}

This is calculated following Staiger and Gaumer (1990). The rate at which hospitals are paid, for the first five years of PPS, is an average of their traditional cost per case and the regional/national average cost per case. After 1988 , hospitals were paid based solely on national average costs, with several remaining exceptions: in some regions, there was still a regional adjustment to reimbursement rates; reimbursement was still adjusted for variations in local labor costs; there were adjustments for teaching hospitals, and hospitals which served a disproportionate share of poor patients; and sole community hospitals continued to be paid based (partially) on their historic costs. The basic formula is:

$$
\begin{aligned}
& \text { BITE }_{t}=- \text { RATE }_{\imath} /\left(\text { BASECOST }^{*}\right. \text { AVGINF) } \\
& \text { RATE }_{\mathrm{t}}=\mathrm{a}_{1} \text { BASECOST*UPDATE }_{\mathrm{t}}+\left(1-\mathrm{a}_{\mathrm{a}}\right)\left(\mathrm{b}_{\mathrm{l}} \mathrm{N}_{\mathrm{t}}+\left(1-\mathrm{b}_{\mathrm{b}}\right) \mathrm{R}_{\mathrm{v}}\right) \\
& *(1+\mathrm{TCH}) *(1+\mathrm{DSH})
\end{aligned}
$$

'I created a similar index for the uninsured only, for use in the uninsured treatment intensity regressions; it was virtually identical (correlation of 0.98 ), so the private pay index was used for both.

${ }^{2}$ The index is quite similar if charges are used instead. I also adjust for variations in area wages, as is done by Medicare. 
where BASECOST is the hospitals case-mix adjusted cost per discharge in 1982

AVGINF, is the statewide rate of hospital cost inflation from 1982 to $t$

UPDATE is the mandated update factor for the hospital specific portion

$a_{1}$ is the blend factor from hospital specific to regional/national average costs (depends on hospital fiscal year)

$b_{1}$ is the blend factor from regional to national average costs (depends on federal fiscal year)

$N_{1}$ is national average costs (labor portion*local wage index + non-labor portion)

$R_{1}$ is regional average costs (labor portion*local wage index + non-labor portion)

$\mathrm{TCH}_{\mathbf{t}}$ is the teaching adjustment, which is a function of the intern/bed ratio

$\mathrm{DSH}_{\mathbf{t}}$ is the disproportionate share adjustment, which is a function of the fraction of patients who are poor

Transition dates and other details of implementation were collected from the Federal Register for the years 1983-1988; many of these details are not reflected in this simplified presentation. The program used to calculate the "bite" is available on request. I do not account for adjustments for "outlier" cases, which I assume is equal to the cost of treating those cases. The data used come from the disclosure report, and from the Health Care Financing Administration's "PPS Impact File".

D) Measures of the Uninsured Population from the CPS

The March CPS has included questions about insurance coverage in the previous year in every year since 1980 . These questions are used to calculate the percent uninsured in each of nine areas in the state: central city Los Angeles, the rest of Los Angeles, six other large SMSAs, and the rest of the state. One important problem, however, is that the structure of this survey was changed in 1988 to account for overcounting of the uninsured in previous years, so that the definition of uninsured is not consistent across years. I account for this by noting (following Bureau of the Census, 1988) that these 
changes would not be expected to affect the definition for individuals 25-54 years old. In fact, nationwide this group had a relatively constant rate of insurance coverage from 1986-1987, while other groups saw a large increase in insurance coverage. Thus, I use this group as a "bridge" across these two years, forcing the change in insurance coverage for other groups across these years to match the change for this group. 


\section{BIBLIOGRAPHY}

Arstein-Kerslake, C. (1988). "Profiles of Orgainizations Contracting with Hospitals". Sacramento, CA: California Association of Hospitals and Health Systems.

Baker, David W. Carl D. Stevens, and Robert H. Brook (1991). "Patients Who Leave a Public Hospital Emergency Department Without Being Seen By a Physician, " Journal of the American Medical Association, 266:1085-1090.

Bindman, Andrew, Kevin Grumbach, Dennis Keane, Loren Rauch, and John Luce (1991). "Consequences of Queuing for Care at a Public Hospital Emergency Department," Joumal of the American Medical Association, 266:1091-1096.

Bureau of the Census (1988). "User Note: Modifications to the March 1988 CPS Health Insurance Questions: Some Preliminary Results". Washington, D.C.: Bureau of the Census.

Butler, Stuar M. and Edmund F. Haislmaier, eds. (1989). A National Health System for America. Washington, D.C.: The Heritage Foundation.

Cutler, David (1991). "Empirical Evidence on Hospital Delivery Under Prospective Payment". Mimeo, MIT.

Dranove, David, Mark Satterthwaite, and Jody Sindelar (1986). "The Effect of Injecting Price Competition into the Hospital Market: The Case of Preferred Provider Organizations," Inquiry, 23:419-431.

Dranove, David, Mark Shanley and William D. White (1991). "Price and Competition in Hospital Markets: The Switch from Patient-driven to Payor-driven Competition". Mimeo.

Enthoven, Alain, and Richard Kronick (1989). "A Consumer-Choice Health Plan for the 1990s," New England Joumal of Medicine, 320:29-37,94-101.

Feder, Judith, Jack Hadley, and Stephen Zuckerman (1987). "How Did Medicare's Prospective Payment System Affect Hospitals," New England Journal of Medicine, 317:867-873.

Frank, Richard G., and David S. Salkever (1991). "The Supply of Charity Services by NonProfit Hospitals: Motives and Market Structure". Mimeo, Johns Hopkins.

Frech, H.E. III (1985). "Preferred Provider Organizations and Health Care Competition," in Health Care in America, H.E. Frech ed. San Francisco: Pacific Research Institute for Public Policy.

Gruber, Jonathan (1991). "What Do PPOs Do?". Mimeo, Harvard University, December. 
Grumbach, Kevin, Andrew Bindman, and Dennis Keane (1991). "Public Hospital Emergency Department Overcrowding: An Excess of Demand or a Demand for Better Primary Care Access?". Mimeo, UC San Francisco.

Hausman, J.A. (1978). "Specification Tests in Econometrics," Econometrica, 46:1251-1270.

Hinden, Richard A. (1989). "Summary of PPO Legislation on a State Level, 1989". Chicago: American Association of Preferred Provider Organizations.

Hosek, Susan D. and M. Susan Marquis (1990). Participation and Satisfaction in Employer Plans with Preferred Provider Organization Options. Santa Monica, CA: RAND.

and Kenneth Wells (1990). Health Care Utilization In Emplover Plans with Preferred Provider Organization Options. Santa Monica, CA: RAND.

Interstudy (various years). The Interstudy Edge. Minneapolis, MN: Interstudy.

Johns, Lucy (1989). "Selective Contracting in California: An Update," Inquiry, 26:345-353.

Robert A. Derzon and Maren Anderson (1985). Selective Contracting for Health Services in California: Final Report. Washington, D.C.: Lewin and Associates.

Marion Merill Dow $(1989,1990)$. "Managed Care Digest: PPO Edition". Kansas City, MO: Marion Merill Dow.

Melnick, Glenn A., Jack Zwanziger, and Tom Bradley (1989). "Competition and Cost Containment in California: 1980-1987," Health Affairs, Summer:129-136.

Newhouse, Joseph (1992). "Medical Care Costs and Medical Care Cost Containment," fortcoming in Journal of Economic Perspectives.

Noether, Monica (1988). "Competition Among Hospitals," Joumal of Health Economics, 7:259284.

Office of Statewide Health Planning and Development (various). Aggregate Hospital Financial Data for California. Sacramento, CA: OSHPD.

ProPAC (1991). Report and Recommendations to the Congress. Washington, D.C.:ProPAC.

Public Citizen (1991). "140 Hospitals Named for Patient Dumping Violations". Washington, D.C.: Public Citizen.

Rezide (1985). Rezide: The National Zip Code Encuclopedia. Alexandria, VA: Claritas.

Rice, Thomas, Greg de Lissovoy, Jon Gabel, and Dan Ermann (1986). "The State of PPOs: Results From a National Survey, "Health Affairs, Winter:25-39. 
Robinson, James C. and Harold Luft (1985). "The Impact of Hospital Market Structure on Patient Volume, Average Length of Stay, and the Cost of Care, "Joumal of Health Economics, 4:333-356.

Robinson, James C. and Clarian S. Phibbs (1989). "An Evaluation of Selective Contracting in California," Journal of Health Economics, 8:437-455.

Rolph, Elizabeth S. et al. (1986). State Laws and Regulations Governing Preferred Provider Organizations. Santa Monica, CA: RAND.

Satterthwaite, Mark A. (1979). "Consumer Information, Equilibrium Industry Price, and the Number of Sellers," Bell Joumal of Economics, 10:483-502.

Saywell, Robert M., Terrell W. Zollinger, David K.W. Chu, Charlotte A. MacBeth, and Mark E. Sechrist (1989). "Hospital and Patient Characteristics of Uncompensated Hospital Care: Policy Implications," Journal of Helath Politics. Policv, and Law, 14:287-307.

Staiger, Douglas, and Gary L.Gaumer (1990). "The Impact of Financial Pressure on Quality of Care in Hospitals: Post-Admission Mortality Under Medicare's Prospective Payment System". Mimeo, Abt Associates.

Thorpe, Kenneth E. and Charles. E. Phelps (1991). "The Social Role of Not-For-Profit Organizations: Hospital Provision of Charity Care," Economic Inquiry, 24:472-484.

and Christine Spencer (1991). "Do Uncompensated Care Pools Increase Access to Care? Results from New York State". Forthcoming, Joumal of Health Politics. Policy, and Iaw.

Weisbrod, Burton (1991). "The Health Care Quadrilemma: An Essay on Technological Change, Insurance, Quality of Care, and Cost Containment," Joumal of Economic Literature, 29:523-552.

Weissman, Joel S., Carol Lucas, and Amold M. Epstein (1990). "Bad Debt, Free Care, and the Problem of Under-Insurance". Mimeo.

White, H. (1980). "A Heteroskedasticity Consistent Covariance Matrix and a Direct Test for Heteroskedasticity," Econometrica, 48:817-838.

Wooley, J. Michael, and H.E. Frech (1989). "How Hospitals Compete: A Review of the Literature," Joumal of Law and Public Policy, 2:57-79.

Zwanziger, Jack and Glenn A. Melnick (1988). "The Effects of Hospital Competition and the Medicare PPS Program on Hospital Cost Behavior in Califomia, "Joumal of Health Economics, 7:301-320. 


\begin{tabular}{|c|c|c|}
\hline Variable & 1984 Mean & 1988 Mean \\
\hline Public Hospital & 0.214 & \\
\hline For-Profit Hospital & 0.159 & \\
\hline Religious Affiliation & 0.127 & \\
\hline Number of admissions & $\begin{array}{c}15219 \\
{[16107]}\end{array}$ & $\begin{array}{c}15446 \\
{[14489]}\end{array}$ \\
\hline Intern/Bed Ratio & 0.093 & \\
\hline Central City & 0.493 & \\
\hline Rural & 0.071 & \\
\hline Sole Community Hospital & 0.016 & \\
\hline \% Uninsured in SMSA & $\begin{array}{c}0.194 \\
{[0.047]}\end{array}$ & $\begin{array}{c}0.212 \\
{[0.050]}\end{array}$ \\
\hline $\begin{array}{l}\text { Median lncome in } \\
\text { Zip Code }\end{array}$ & $\begin{array}{l}16177 \\
{[3309]}\end{array}$ & $\begin{array}{r}18674 \\
{[3923]}\end{array}$ \\
\hline Discount/Non-gov revs & $\begin{array}{c}0.019 \\
{[0.029]}\end{array}$ & $\begin{array}{c}0.112 \\
{[0.090]}\end{array}$ \\
\hline$\Delta$ BiteShare & $\begin{array}{c}0.033 \\
{[0.019]}\end{array}$ & $\begin{array}{c}0.072 \\
{[0.055]}\end{array}$ \\
\hline 1982 Medi-Cal Share & $\begin{array}{c}0.165 \\
{[0.129]}\end{array}$ & \\
\hline $\begin{array}{l}\text { Log (Operating } \\
\text { Expenses) }\end{array}$ & $\begin{array}{c}17.57 \\
{[0.94]}\end{array}$ & $\begin{array}{l}17.94 \\
{[0.91]}\end{array}$ \\
\hline Uncompensated care/revenues & $\begin{array}{c}0.060 \\
{[0.098]}\end{array}$ & $\begin{array}{c}0.076 \\
{[0.113]}\end{array}$ \\
\hline Patient Origin Herfindahl & $\begin{array}{c}0.253 \\
{[0.116]}\end{array}$ & \\
\hline Number of Observations & 398 & 398 \\
\hline
\end{tabular}

Notes:

1) All means are weighted by total hospitat admissions in 1988 .

2) Standard deviations in square brackets.

3) Sources: Annual Disclosure Report (hospital control and location variables, discounts, Medi-Cal share, operating expenses, uncompensated care), Discharge Dataset (admissions, herfindah), HCFA "Impact" File (sole community hospital, intern/bed ratio), Current Population Survey (\% uninsured), calculations using Impact File and Disclosure report data ( $\triangle$ BiteShare - described in Appeodix B), and Rezide (1985) (income by zip code). 


\begin{tabular}{|c|c|c|c|c|c|c|}
\hline \multicolumn{7}{|c|}{$\begin{array}{c}\text { Table 2: Price Shopping, Discounts, and Net Prices } \\
\text { All regressions in changes }\end{array}$} \\
\hline Column & (1) & (2) & (3) & (4) & (5) & (6) \\
\hline $\begin{array}{l}\text { Dependent } \\
\text { Variable }\end{array}$ & $\begin{array}{c}\Delta \text { DiscnV } \\
\text { NGPR } \\
1984-88\end{array}$ & $\begin{array}{c}\triangle D i s c n U / \\
\text { NGPR } \\
1984-88\end{array}$ & $\begin{array}{l}\Delta \text { Nex NG } \\
\text { Rev/Day } \\
1984-88\end{array}$ & $\begin{array}{c}\Delta N e t N G \\
\text { Rev/Dey } \\
1984-1988\end{array}$ & $\begin{array}{c}\Delta \text { DiscnV } \\
\text { NGPR } \\
\text { 1982-84 }\end{array}$ & $\begin{array}{l}\Delta \mathrm{Net} M \mathrm{Mal} \\
\text { Rev/Duy }\end{array}$ \\
\hline $\begin{array}{l}\text { Patient Origin } \\
\text { Herfindahl }\end{array}$ & $\begin{array}{r}-0.134 \\
(0.041)\end{array}$ & $\begin{array}{r}-0.241 \\
(0.054)\end{array}$ & $\begin{array}{r}0.275 \\
(0.153)\end{array}$ & $\begin{array}{c}0.289 \\
(0.154)\end{array}$ & $\begin{array}{r}-0.003 \\
(0.029)\end{array}$ & $\begin{array}{r}0.214 \\
(0.597)\end{array}$ \\
\hline One std der $\Delta$ & -0.016 & -0.028 & 0.035 & 0.034 & -0.0003 & 0.025 \\
\hline$\Delta$ BileShare & $\begin{array}{l}-0.138 \\
(0.087)\end{array}$ & $\begin{array}{c}-0.107 \\
(0.091)\end{array}$ & $\begin{array}{r}-0.132 \\
(0.260)\end{array}$ & $\begin{array}{r}-0.190 \\
(0.262)\end{array}$ & $\begin{array}{c}0.271 \\
(0.136)\end{array}$ & $\begin{array}{c}0.047 \\
(1.041)\end{array}$ \\
\hline $\begin{array}{l}\text { Public } \\
\text { Hospital }\end{array}$ & $\begin{array}{r}-0.057 \\
(0.012)\end{array}$ & $\begin{array}{l}-0.056 \\
(0.012)\end{array}$ & $\begin{array}{r}0.009 \\
(0.036)\end{array}$ & $\begin{array}{c}0.003 \\
(0.036)\end{array}$ & $\begin{array}{c}-0.002 \\
(0.007)\end{array}$ & $\begin{array}{c}0.458 \\
(0.136)\end{array}$ \\
\hline $\begin{array}{l}\text { For-Profiı } \\
\text { Hospital }\end{array}$ & $\begin{array}{l}-0.058 \\
(0.012)\end{array}$ & $\begin{array}{r}-0.046 \\
(0.013)\end{array}$ & $\begin{array}{r}0.058 \\
(0.036)\end{array}$ & $\begin{array}{c}0.053 \\
(0.036)\end{array}$ & $\begin{array}{c}-0.005 \\
(0.007)\end{array}$ & $\begin{array}{l}-0.296 \\
(0.153)\end{array}$ \\
\hline $\begin{array}{l}\text { Religiuus } \\
\text { Aftiliation }\end{array}$ & $\begin{array}{c}0.008 \\
(0.013)\end{array}$ & $\begin{array}{r}0.007 \\
(0.013)\end{array}$ & $\begin{array}{c}-0.059 \\
(0.036)\end{array}$ & $\begin{array}{c}-0.058 \\
(0.036)\end{array}$ & $\begin{array}{c}0.001 \\
(0.008)\end{array}$ & $\begin{array}{c}0.060 \\
(0.143)\end{array}$ \\
\hline $\begin{array}{c}\text { Intern/Bed } \\
\text { Ratio }\end{array}$ & $\begin{array}{r}-0.040 \\
(0.030)\end{array}$ & $\begin{array}{c}-0.037 \\
(0.030)\end{array}$ & $\begin{array}{c}0.121 \\
(0.086)\end{array}$ & $\begin{array}{c}0.100 \\
(0.087)\end{array}$ & $\begin{array}{c}-0.019 \\
(0.017)\end{array}$ & $\begin{array}{c}0.393 \\
(0.331)\end{array}$ \\
\hline Log (Bads) & $\begin{array}{c}0.009 \\
(0.007)\end{array}$ & $\begin{array}{c}0.021 \\
(0.008)\end{array}$ & $\begin{array}{l}0.0004 \\
(0.023)\end{array}$ & $\begin{array}{c}0.003 \\
(0.023)\end{array}$ & $\begin{array}{c}0.003 \\
(0.004)\end{array}$ & $\begin{array}{c}-0.104 \\
(0.093)\end{array}$ \\
\hline $\begin{array}{l}\text { Central } \\
\text { City }\end{array}$ & $\begin{array}{c}0.017 \\
(0.009)\end{array}$ & $\begin{array}{c}0.010 \\
(0.009)\end{array}$ & $\begin{array}{c}0.005 \\
(0.026)\end{array}$ & $\begin{array}{l}-0.003 \\
(0.027)\end{array}$ & $\begin{array}{c}-0.003 \\
(0.005)\end{array}$ & $\begin{array}{c}-0.027 \\
(0.108)\end{array}$ \\
\hline Rural & $\begin{array}{c}-0.007 \\
(0.017)\end{array}$ & $\begin{array}{r}-0.012 \\
(0.022)\end{array}$ & $\begin{array}{r}0.107 \\
(0.064)\end{array}$ & $\begin{array}{c}0.118 \\
(0.064)\end{array}$ & $\begin{array}{c}-0.001 \\
(0.012)\end{array}$ & $\begin{array}{c}-0.190 \\
(0.244)\end{array}$ \\
\hline $\begin{array}{c}\text { Medi-Cal } 1982 \\
\text { Share }\end{array}$ & $\begin{array}{c}-0.187 \\
(0.048)\end{array}$ & $\begin{array}{c}-0.198 \\
(0.049)\end{array}$ & $\begin{array}{l}-0.146 \\
(0.139)\end{array}$ & $\begin{array}{c}-0.143 \\
(0.140)\end{array}$ & $\begin{array}{r}0.038 \\
(0.026)\end{array}$ & $\begin{array}{c}-0.581 \\
(0.544)\end{array}$ \\
\hline $\begin{array}{l}\text { Change in } \\
\text { Priv CMIl }\end{array}$ & & & & $\begin{array}{c}0.156 \\
(0.079)\end{array}$ & & \\
\hline $\begin{array}{l}\Delta \text { Log Priv } \\
\text { Procolures }\end{array}$ & & & & $\begin{array}{c}0.063 \\
(0.045)\end{array}$ & & \\
\hline $\begin{array}{l}\text { 14 IISA } \\
\text { Dummuies }\end{array}$ & No & $\begin{array}{c}\text { Yes } \\
{[0.003]}\end{array}$ & $\begin{array}{c}\text { Yes } \\
{[0.004]}\end{array}$ & $\begin{array}{c}\text { Yes } \\
{[0.006]}\end{array}$ & $\begin{array}{c}\text { Yes } \\
{[0.254]}\end{array}$ & $\begin{array}{c}\text { Yes } \\
{[0.002]}\end{array}$ \\
\hline.$V$ & 390 & 390 & 390 & 386 & 390 & 335 \\
\hline
\end{tabular}

Nores:

1) Standard errors in parencheses; all regressions weighted hy total hospital admissions in 1988 .

2) $\triangle$ Disint/NGPR = change in discounts over non-govemnent revenues, 1984-88.

3) SNet NG Rev/Day = change in non-govemment revenues minus discuunts over non-gov didys.

4) SNet MCal Rev/Day = chinge in Medi-Cal revenues minus Medi-Cal discounts over Modi-Cal days.

5) The second row gives the change in the dependent variable for a one standard deviation change in the berfindahl.

6) Number in brackets in HSA Dummies row is significance level for a joint F test of the HSA dunumies. 


\begin{tabular}{|c|c|c|c|c|c|c|}
\hline Specification & $\begin{array}{c}(1) \\
\Delta \text { Log } \\
\text { Expenses }\end{array}$ & $\begin{array}{c}\text { (2) } \\
\Delta \text { Log } \\
\text { Expenses }\end{array}$ & $\begin{array}{c}\text { (3) } \\
\Delta \mathrm{Log} \\
\text { Expenses }\end{array}$ & $\begin{array}{l}\text { (4) } \\
\text { Log LOS } \\
\text { Diff }\end{array}$ & $\begin{array}{c}\text { (5) } \\
\text { Log Avg } \\
\text { Chg Diff }\end{array}$ & $\begin{array}{c}\text { (6) } \\
\text { Log CM1 } \\
\text { Diff }\end{array}$ \\
\hline Years & $1984-88$ & $1984-88$ & $1982-84$ & 1988 & 1988 & 1988 \\
\hline $\begin{array}{l}\text { Patient Origin } \\
\text { llerlindahl }\end{array}$ & $\begin{array}{c}0.121 \\
(0.061)\end{array}$ & $\begin{array}{l}-0.049 \\
(0.080)\end{array}$ & $\begin{array}{c}0.028 \\
(0.068)\end{array}$ & $\begin{array}{l}-0.145 \\
(0.159)\end{array}$ & $\begin{array}{c}0.068 \\
(0.094)\end{array}$ & $\begin{array}{r}0.065 \\
(0.232)\end{array}$ \\
\hline One sid der $\Delta$ & 0.014 & -0.006 & 0.003 & -0.017 & 0.008 & 0.008 \\
\hline SBiteShare & $\begin{array}{l}-0.687 \\
(0.130)\end{array}$ & $\begin{array}{l}-0.647 \\
(0.137)\end{array}$ & $\begin{array}{l}-1.826 \\
(0.315)\end{array}$ & $\begin{array}{r}-0.189 \\
(0.143)\end{array}$ & $\begin{array}{c}0.013 \\
(0.084)\end{array}$ & $\begin{array}{c}0.294 \\
(0.209)\end{array}$ \\
\hline $\begin{array}{l}\text { Public } \\
\text { Hospital }\end{array}$ & $\begin{array}{c}0.019 \\
(0.018)\end{array}$ & $\begin{array}{c}0.044 \\
(0.019)\end{array}$ & $\begin{array}{c}0.016 \\
(0.016)\end{array}$ & $\begin{array}{c}-0.004 \\
(0.039)\end{array}$ & $\begin{array}{c}0.008 \\
(0.023)\end{array}$ & $\begin{array}{r}-0.015 \\
(0.057)\end{array}$ \\
\hline $\begin{array}{c}\text { For-Profit } \\
\text { Hospital }\end{array}$ & $\begin{array}{c}-0.015 \\
(0.019)\end{array}$ & $\begin{array}{l}-0.019 \\
(0.019)\end{array}$ & $\begin{array}{c}-0.032 \\
(0.015)\end{array}$ & $\begin{array}{c}0.015 \\
(0.030)\end{array}$ & $\begin{array}{l}-0.026 \\
(0.018)\end{array}$ & $\begin{array}{c}-0.067 \\
(0.044)\end{array}$ \\
\hline $\begin{array}{l}\text { Religious } \\
\text { Affiliation }\end{array}$ & $\begin{array}{r}-0.006 \\
(0.018)\end{array}$ & $\begin{array}{c}-0.017 \\
(0.018 ;\end{array}$ & $\begin{array}{c}-0.019 \\
(0.018)\end{array}$ & $\begin{array}{c}0.042 \\
(0.030)\end{array}$ & $\begin{array}{l}-0.009 \\
(0.018)\end{array}$ & $\begin{array}{c}0.011 \\
(0.044)\end{array}$ \\
\hline $\begin{array}{l}\text { Intern/Bed } \\
\text { Ratio }\end{array}$ & $\begin{array}{l}-0.019 \\
(0.046)\end{array}$ & $\begin{array}{r}0.013 \\
(0.046)\end{array}$ & $\begin{array}{c}-0.098 \\
(0.039)\end{array}$ & $\begin{array}{c}0.067 \\
(0.090)\end{array}$ & $\begin{array}{c}0.003 \\
(0.053)\end{array}$ & $\begin{array}{r}-0.266 \\
(0.132)\end{array}$ \\
\hline Log (Beds) & $\begin{array}{l}-0.012 \\
(0.011)\end{array}$ & $\begin{array}{r}-0.005 \\
(0.012)\end{array}$ & $\begin{array}{l}-0.005 \\
(0.010)\end{array}$ & $\begin{array}{c}0.052 \\
(0.021)\end{array}$ & $\begin{array}{c}0.007 \\
(0.013)\end{array}$ & $\begin{array}{r}-0.100 \\
(0.031)\end{array}$ \\
\hline $\begin{array}{c}\text { Cintral } \\
\text { City }\end{array}$ & $\begin{array}{c}-0.002 \\
(0.013)\end{array}$ & $\begin{array}{l}-0.008 \\
(0.014)\end{array}$ & $\begin{array}{c}0.004 \\
(0.011)\end{array}$ & $\begin{array}{l}-0.068 \\
(0.023)\end{array}$ & $\begin{array}{c}0.006 \\
(0.014)\end{array}$ & $\begin{array}{l}0.086 \\
(0.034)\end{array}$ \\
\hline Rural & $\begin{array}{c}0.029 \\
(0.026)\end{array}$ & $\begin{array}{l}-0.004 \\
(0.034)\end{array}$ & $\begin{array}{c}0.008 \\
(0.028)\end{array}$ & $\begin{array}{c}0.003 \\
(0.069)\end{array}$ & $\begin{array}{l}0.048 \\
(0.041)\end{array}$ & $\begin{array}{c}0.046 \\
(0.101)\end{array}$ \\
\hline $\begin{array}{c}\text { Medi-Cal } 1982 \\
\text { Share }\end{array}$ & $\begin{array}{l}-0.325 \\
(0.074)\end{array}$ & $\begin{array}{c}-0.403 \\
(0.074)\end{array}$ & $\begin{array}{c}-0.234 \\
(0.060)\end{array}$ & $\begin{array}{r}-0.019 \\
(0.149)\end{array}$ & $\begin{array}{c}-0.015 \\
(0.088)\end{array}$ & $\begin{array}{r}-0.006 \\
(0.218)\end{array}$ \\
\hline $\begin{array}{c}\text { Change in } \\
\text { CMII }\end{array}$ & $\begin{array}{c}0.473 \\
(0.061)\end{array}$ & $\begin{array}{l}0.466 \\
(0.061)\end{array}$ & & & & \\
\hline $\begin{array}{c}\text { Change in Log } \\
\text { Discharges }\end{array}$ & $\begin{array}{c}0.613 \\
(0.029)\end{array}$ & $\begin{array}{l}0.602 \\
(0.029)\end{array}$ & $\begin{array}{l}0.605 \\
(0.035)\end{array}$ & & & \\
\hline $\begin{array}{l}\text { 14 HSA } \\
\text { Dummies }\end{array}$ & No & $\begin{array}{c}\text { Yes } \\
{[0.001]}\end{array}$ & $\begin{array}{c}\text { Yes } \\
{[0.001]}\end{array}$ & $\begin{array}{c}\text { Yea } \\
{[0.006]}\end{array}$ & $\begin{array}{c}\text { Yes } \\
[0.36]]\end{array}$ & $\begin{array}{c}\text { Yea } \\
{[0.048]}\end{array}$ \\
\hline $\mathbf{N}$ & 398 & 398 & 398 & 309 & 309 & 309 \\
\hline
\end{tabular}

Nolcs:

1) Standard errors in parentheses; colurnn (1)-(3) weighted by tolal houpital admissions in 1988.

2) CMIl is case mix index for all hospital patients, where calculation of weights is described in appendix.

3) Change in Log Discharges is the change in the log of hospizal discharges from the disclosure report.

4) Columns (4)-(6) run as levels for 1988.

5) The dependent variable in column (4) is the difference between the $\log$ of the avernge kength of stay for PPO patients and the log average length of stay for the unditionally insured; in column (5), it is the difference in log overnge charges; in column (6), it is the difference in the case mix index.

6) Columns (4)-(6) are weighted by: $\frac{n_{1}^{*} n_{1}}{\left(n_{1}+n_{2}\right)}$

where $n_{1}$ is PPO admits, and $m_{2}$ is traditionally insured admits. 


\begin{tabular}{|c|c|c|c|c|c|}
\hline \multicolumn{6}{|c|}{$\begin{array}{l}\text { Table 4: Competitive Pressure and Uncompensated Care } \\
\text { Deprendent Variable is Change in Log Uncompensated Care }\end{array}$} \\
\hline Specification & $\begin{array}{l}(1) \\
1984-88 \\
\text { OLS }\end{array}$ & $\begin{array}{l}(2) \\
\text { 1984-88 } \\
\text { OLS }\end{array}$ & $\begin{array}{l}\text { (3) } \\
\text { 1982-84 } \\
\text { OLS }\end{array}$ & $\begin{array}{l}\text { (4) } \\
1984-88 \\
\text { OLS }\end{array}$ & $\begin{array}{l}\text { (5) } \\
\text { 1984-88 } \\
\text { TSLS }\end{array}$ \\
\hline $\begin{array}{l}\text { Patient Oriyin } \\
\text { Ilerfiadahl }\end{array}$ & $\begin{array}{r}0.673 \\
(0.335)\end{array}$ & $\begin{array}{r}0.872 \\
(0.427)\end{array}$ & $\begin{array}{c}-0.136 \\
(0.428)\end{array}$ & & \\
\hline One std dep & 0.078 & 0.101 & -0.016 & & \\
\hline $\begin{array}{l}\text { IDiscount } \\
\text { GPR }\end{array}$ & & & & $\begin{array}{l}-3.352 \\
(0.690)\end{array}$ & $\begin{array}{l}-7.669 \\
(3.855)\end{array}$ \\
\hline $\begin{array}{l}\text { IS UC for a } \\
\text { SI } \triangle \text { Discount }\end{array}$ & & & & -0.231 & -0.529 \\
\hline$\Delta B$ Biteshare & $\begin{array}{c}0.401 \\
(0.678)\end{array}$ & $\begin{array}{c}0.121 \\
(0.729)\end{array}$ & $\begin{array}{r}1.685 \\
(1.976)\end{array}$ & $\begin{array}{l}-0.155 \\
(0.709)\end{array}$ & $\begin{array}{r}-0.353 \\
(0.766)\end{array}$ \\
\hline $\begin{array}{l}\text { Change in } \% \\
\text { Unins in SMSA }\end{array}$ & $\begin{array}{c}1.048 \\
(1.352)\end{array}$ & $\begin{array}{l}-3.502 \\
(6.737)\end{array}$ & $\begin{array}{l}8.864 \\
(6.739)\end{array}$ & $\begin{array}{c}-0.821 \\
(6.241)\end{array}$ & $\begin{array}{l}2.847 \\
(7.309)\end{array}$ \\
\hline $\begin{array}{l}\text { Log Zip Code } \\
\text { Income }\end{array}$ & $\begin{array}{c}0.200 \\
(0.187)\end{array}$ & $\begin{array}{c}0.429 \\
(0.225)\end{array}$ & $\begin{array}{c}0.040 \\
(0.203)\end{array}$ & $\begin{array}{c}0.506 \\
(0.220)\end{array}$ & $\begin{array}{c}0.681 \\
(0.277)\end{array}$ \\
\hline $\begin{array}{l}\text { Public } \\
\text { Hospital }\end{array}$ & $\begin{array}{r}0.133 \\
(0.093)\end{array}$ & $\begin{array}{r}0.160 \\
(0.100)\end{array}$ & $\begin{array}{c}0.189 \\
(0.098)\end{array}$ & $\begin{array}{r}0.101 \\
(0.097)\end{array}$ & $\begin{array}{l}-0.038 \\
(0.159)\end{array}$ \\
\hline $\begin{array}{l}\text { For-Profit } \\
\text { Hospital }\end{array}$ & $\begin{array}{r}0.057 \\
(0.096)\end{array}$ & $\begin{array}{c}0.064 \\
(0.099)\end{array}$ & $\begin{array}{c}-0.068 \\
(0.094)\end{array}$ & $\begin{array}{l}-0.013 \\
(0.097)\end{array}$ & $\begin{array}{l}-0.089 \\
(0.122)\end{array}$ \\
\hline $\begin{array}{l}\text { Religious } \\
\text { Affiliation }\end{array}$ & $\begin{array}{r}0.138 \\
(0.094)\end{array}$ & $\begin{array}{c}0.154 \\
(0.097)\end{array}$ & $\begin{array}{l}-0.180 \\
(0.109)\end{array}$ & $\begin{array}{r}0.148 \\
(0.095)\end{array}$ & $\begin{array}{c}0.159 \\
(0.100)\end{array}$ \\
\hline $\begin{array}{l}\text { InterniBid } \\
\text { Ratio }\end{array}$ & $\begin{array}{l}-0.536 \\
(0.233)\end{array}$ & $\begin{array}{c}-0.493 \\
(0.241)\end{array}$ & $\begin{array}{r}-0.024 \\
(0.248)\end{array}$ & $\begin{array}{c}-0.584 \\
(0.236)\end{array}$ & $\begin{array}{l}-0.706 \\
(0.270)\end{array}$ \\
\hline Log (Buds) & $\begin{array}{r}-0.047 \\
(0.056)\end{array}$ & $\begin{array}{l}-0.068 \\
(0.064)\end{array}$ & $\begin{array}{l}-0.061 \\
(0.059)\end{array}$ & $\begin{array}{c}-0.009 \\
(0.062)\end{array}$ & $\begin{array}{r}0.044 \\
(0.080)\end{array}$ \\
\hline $\begin{array}{l}\text { Central } \\
\text { City }\end{array}$ & $\begin{array}{r}-0.015 \\
(0.071)\end{array}$ & $\begin{array}{l}-0.024 \\
(0.085)\end{array}$ & $\begin{array}{c}0.090 \\
(0.079)\end{array}$ & $\begin{array}{l}-0.001 \\
(0.083)\end{array}$ & $\begin{array}{r}0.043 \\
(0.095)\end{array}$ \\
\hline Rural & $\begin{array}{l}-0.007 \\
(0.134)\end{array}$ & $\begin{array}{c}-0.069 \\
(0.182)\end{array}$ & $\begin{array}{r}0.070 \\
(0.177)\end{array}$ & $\begin{array}{l}-0.055 \\
(0.178)\end{array}$ & $\begin{array}{l}-0.033 \\
(0.188)\end{array}$ \\
\hline $\begin{array}{l}\text { Medi-Cal } 1982 \\
\text { Share }\end{array}$ & $\begin{array}{r}0.961 \\
(0.397)\end{array}$ & $\begin{array}{c}0.934 \\
(0.407)\end{array}$ & $\begin{array}{r}0.496 \\
(0.387)\end{array}$ & $\begin{array}{c}0.587 \\
(0.385)\end{array}$ & $\begin{array}{r}0.410 \\
(0.434)\end{array}$ \\
\hline $\begin{array}{l}\text { Sule Community } \\
\text { Hospital }\end{array}$ & $\begin{array}{c}.0 .332 \\
(0.259)\end{array}$ & $\begin{array}{c}-0.289 \\
(0.274)\end{array}$ & $\begin{array}{r}0.001 \\
(0.251)\end{array}$ & $\begin{array}{r}-0.239 \\
(0.266)\end{array}$ & $\begin{array}{l}-0.255 \\
(0.280)\end{array}$ \\
\hline $\begin{array}{l}\text { Change in Log } \\
\text { Gross Pal Revs }\end{array}$ & $\begin{array}{c}1.041 \\
(0.148)\end{array}$ & $\begin{array}{c}0.954 \\
(0.160)\end{array}$ & $\begin{array}{c}1.473 \\
(0.211)\end{array}$ & $\begin{array}{l}1.121 \\
(0.159)\end{array}$ & $\begin{array}{c}1.331 \\
(0.249)\end{array}$ \\
\hline $\begin{array}{l}1+\text { HSA } \\
\text { Dummies }\end{array}$ & No & $\begin{array}{c}Y(x) \\
{[0.671]}\end{array}$ & $\begin{array}{c}Y=9 \\
{[0.400]}\end{array}$ & $\begin{array}{c}\text { Yes } \\
{[0.449]}\end{array}$ & $\begin{array}{c}\text { Yes } \\
\text { |0.402| }\end{array}$ \\
\hline$N$ & 398 & 398 & 396 & 398 & 398 \\
\hline
\end{tabular}

Ste page julluwing Table 5 . 


\begin{tabular}{|c|c|c|c|c|c|c|}
\hline \multicolumn{7}{|c|}{$\begin{array}{l}\text { Table 5: How do Hospitals Adjust Uncompensaled Care? } \\
\text { All Regressions Run Over Uhe 1984-1988 Period }\end{array}$} \\
\hline Specification & $\begin{array}{c}\text { (I) } \\
\Delta U C \\
\text { Adm }\end{array}$ & $\begin{array}{l}(2) \\
\Delta U C \\
L O S\end{array}$ & $\begin{array}{c}\text { (3) } \\
\Delta U C \\
\text { Avg Chg }\end{array}$ & $\begin{array}{c}\text { (4) } \\
\Delta \log _{\text {g }} E R \\
\text { Visitu }\end{array}$ & $\begin{array}{c}\text { (5) } \\
\Delta \text { Log } E R \\
\text { Gr Revs }\end{array}$ & $\begin{array}{c}\text { (6) } \\
\text { ALog ER } \\
\text { Gr Revs }\end{array}$ \\
\hline $\begin{array}{l}\text { Patient Origin } \\
\text { llerfindahl }\end{array}$ & $\begin{array}{c}-0.171 \\
(0.481)\end{array}$ & $\begin{array}{c}-0.217 \\
(0.210)\end{array}$ & $\begin{array}{r}0.075 \\
(0.100)\end{array}$ & $\begin{array}{c}0.474 \\
(0.300)\end{array}$ & $\begin{array}{c}0.604 \\
(0.284)\end{array}$ & \\
\hline One std der $\Delta$ & 0.020 & -0.025 & 0.009 & 0.055 & 0.070 & \\
\hline $\begin{array}{l}\text { SDiscounts/ } \\
\text { Revenues }\end{array}$ & & & & & & $\begin{array}{r}-6.099 \\
(3.522)\end{array}$ \\
\hline $\begin{array}{l}\text { AS E.R Revs } \\
\text { lor } 1 S \Delta \text { Disc }\end{array}$ & & & & & & -0.155 \\
\hline SBiteshare & $\begin{array}{r}1.096 \\
(0.813)\end{array}$ & $\begin{array}{r}0.331 \\
(0.366)\end{array}$ & $\begin{array}{r}0.118 \\
(0.176)\end{array}$ & $\begin{array}{l}-0.018 \\
(0.515)\end{array}$ & $\begin{array}{c}0.741 \\
(0.487)\end{array}$ & $\begin{array}{r}0.146 \\
(0.662)\end{array}$ \\
\hline $\begin{array}{l}\text { Change in } \% \\
\text { Unins in SMSA }\end{array}$ & $\begin{array}{l}-10.59 \\
(7.228)\end{array}$ & $\begin{array}{c}0.955 \\
(2.946)\end{array}$ & $\begin{array}{l}-1.784 \\
(1.401)\end{array}$ & $\begin{array}{l}-10.072 \\
(4.540)\end{array}$ & $\begin{array}{c}3.318 \\
(4.374)\end{array}$ & $\begin{array}{c}6.831 \\
(5.794)\end{array}$ \\
\hline $\begin{array}{c}\text { Log Zip } \\
\text { Code Income }\end{array}$ & $\begin{array}{l}-0.038 \\
(0.255)\end{array}$ & $\begin{array}{l}-0.105 \\
(0.108)\end{array}$ & $\begin{array}{c}0.007 \\
(0.052)\end{array}$ & $\begin{array}{l}-0.165 \\
(0.156)\end{array}$ & $\begin{array}{l}0.147 \\
(0.148)\end{array}$ & $\begin{array}{r}0.415 \\
(0.253)\end{array}$ \\
\hline $\begin{array}{l}\text { Public } \\
\text { Hospital }\end{array}$ & $\begin{array}{r}0.095 \\
(0.112)\end{array}$ & $\begin{array}{c}0.082 \\
(0.050)\end{array}$ & $\begin{array}{l}0.042 \\
(0.024)\end{array}$ & $\begin{array}{r}-0.025 \\
(0.070)\end{array}$ & $\begin{array}{l}-0.180 \\
(0.067)\end{array}$ & $\begin{array}{l}-0.339 \\
(0.137)\end{array}$ \\
\hline $\begin{array}{l}\text { For-Profit } \\
\text { Hospilal }\end{array}$ & $\begin{array}{l}-0.098 \\
(0.114)\end{array}$ & $\begin{array}{l}-0.077 \\
(0.051)\end{array}$ & $\begin{array}{r}-0.009 \\
(0.024)\end{array}$ & $\begin{array}{r}-0.120 \\
(0.070)\end{array}$ & $\begin{array}{l}-0.182 \\
(0.067)\end{array}$ & $\begin{array}{c}-0.309 \\
(0.106)\end{array}$ \\
\hline $\begin{array}{l}\text { Religious } \\
\text { Affiliation }\end{array}$ & $\begin{array}{c}0.048 \\
(0.113)\end{array}$ & $\begin{array}{l}-0.043 \\
(0.055)\end{array}$ & $\begin{array}{r}0.009 \\
(0.026)\end{array}$ & $\begin{array}{c}-0.033 \\
(0.068)\end{array}$ & $\begin{array}{l}-0.081 \\
(0.067)\end{array}$ & $\begin{array}{l}-0.103 \\
(0.082)\end{array}$ \\
\hline $\begin{array}{c}\text { Intem/Bed } \\
\text { Ratio }\end{array}$ & $\begin{array}{c}-0.303 \\
(0.27 i)\end{array}$ & $\begin{array}{l}-0.177 \\
(0.123)\end{array}$ & $\begin{array}{l}-0.144 \\
(0.058)\end{array}$ & $\begin{array}{l}-0.160 \\
(0.169)\end{array}$ & $\begin{array}{c}-0.243 \\
(0.160)\end{array}$ & $\begin{array}{l}-0.360 \\
(0.208)\end{array}$ \\
\hline $\log$ (Beds) & $\begin{array}{c}-0.019 \\
(0.072)\end{array}$ & $\begin{array}{c}-0.049 \\
(0.033)\end{array}$ & $\begin{array}{c}0.012 \\
(0.016)\end{array}$ & $\begin{array}{c}-0.046 \\
(0.046)\end{array}$ & $\begin{array}{l}-0.034 \\
(0.044)\end{array}$ & $\begin{array}{r}0.040 \\
(0.064)\end{array}$ \\
\hline $\begin{array}{l}\text { Central } \\
\text { Ciny }\end{array}$ & $\begin{array}{l}-0.164 \\
(0.096)\end{array}$ & $\begin{array}{c}0.072 \\
(0.042)\end{array}$ & $\begin{array}{l}-0.028 \\
(0.020)\end{array}$ & $\begin{array}{c}-0.079 \\
(0.059)\end{array}$ & $\begin{array}{l}-0.038 \\
(0.057)\end{array}$ & $\begin{array}{r}0.027 \\
(0.081)\end{array}$ \\
\hline Rural & $\begin{array}{r}0.038 \\
(0.208)\end{array}$ & $\begin{array}{l}-0.082 \\
(0.081)\end{array}$ & $\begin{array}{l}-0.015 \\
(0.039)\end{array}$ & $\begin{array}{c}0.016 \\
(0.127)\end{array}$ & $\begin{array}{c}0.051 \\
(0.119)\end{array}$ & $\begin{array}{r}0.070 \\
(0.147)\end{array}$ \\
\hline $\begin{array}{l}\text { Medi-Cal } 1982 \\
\text { Share }\end{array}$ & $\begin{array}{r}0.502 \\
(0.464)\end{array}$ & $\begin{array}{c}0.185 \\
(0.203)\end{array}$ & $\begin{array}{c}0.028 \\
(0.098)\end{array}$ & $\begin{array}{c}0.093 \\
(0.290)\end{array}$ & $\begin{array}{c}1.077 \\
(0.276)\end{array}$ & $\begin{array}{r}0.586 \\
(0.380)\end{array}$ \\
\hline $\begin{array}{l}\text { Solt: Community } \\
\text { Hlospital }\end{array}$ & $\begin{array}{l}-0.331 \\
(0.307)\end{array}$ & $\begin{array}{r}0.038 \\
(0.110)\end{array}$ & $\begin{array}{l}-0.009 \\
(0.052)\end{array}$ & $\begin{array}{l}-0.067 \\
(0.191)\end{array}$ & $\begin{array}{c}0.122 \\
(0.180)\end{array}$ & $\begin{array}{r}0.118 \\
(0.221)\end{array}$ \\
\hline $\begin{array}{l}\Delta \text { Log } \\
\text { Priv Control }\end{array}$ & $\begin{array}{c}0.115 \\
(0.105)\end{array}$ & $\begin{array}{c}0.735 \\
(0.091)\end{array}$ & $\begin{array}{c}0.858 \\
(0.055)\end{array}$ & & $\begin{array}{c}0.884 \\
(0.067)\end{array}$ & $\begin{array}{c}0.948 \\
(0.091)\end{array}$ \\
\hline $\begin{array}{l}14 \text { HSA } \\
\text { Dummics }\end{array}$ & $\begin{array}{c}\text { Yes } \\
{[0.024]}\end{array}$ & $\underset{[0.287]}{\text { res }}$ & $\begin{array}{c}\text { Ycs } \\
|0.220|\end{array}$ & $\begin{array}{c}\text { Yes } \\
{[0.000]}\end{array}$ & $\begin{array}{c}\text { Yes } \\
{[0.777]}\end{array}$ & $\begin{array}{c}\text { Ycs } \\
{[0.914]}\end{array}$ \\
\hline$N$ & 388 & 388 & 388 & 373 & 366 & 366 \\
\hline
\end{tabular}

\footnotetext{
Sec next page.
} 


\section{Nives to Table 4:}

1) Stundard errors in parentheses.

2) All regressions weighted by 1988 total admissions.

3) Change in discounts over revenues is the change in discounts to private payers over total gross patieat revenues.

4) In columns (5), change in discounts over gross patieat revenues is instrumeated by the patient origin berfindahl. 5) In columns (4) and (5), cbange in dollars of uncompensated care for a $\$ 1$ change in discounts is evaluated at average uncompensiled care over revenues for 1984 and 1988.

6) Change in percent uninsured is the change in the fraction of the area population without health insurance. Sxe Lati appendix for details of its calculation.

7) Log zip code income is the loy of the median area income by zip code of patient residence, from Rezide (1985). 8) Sule community hospital is a dummy whicb equals one if the hospital is the only source of care in the area, as detined by Medicare.

\section{Noles wa Tahie 5:}

1) Stanclard errors in parentheses.

2) Columns (1), (4)-(6) weighted by total hospital admissions.

3) Columns (2) and (3) are weighted by:

$$
\overline{\left(a_{1}+n_{2}\right)}
$$

where $n_{1}$ is current uninsured admits, and $a_{2}$ is lagged uninsured admits.

1) UC Admits is self-pay admissions.

5) UC LOS is casse mix adjusted length of stay for self-pay paitents; UC Avy Chgs is case mix adjusled average charges per admil; the severity weigbts are described in the date appendix.

6) ER visits is total emergency room visits.

7) ER Gross Revs is total emergency room gross revenues.

8) Change in discounts over revenues is the change in discounts to private payers over total gross patient revenues. 9) In the last column, the change in discounts is instrumented by the berfindahl. The change in emergency room revenues for a $\$ 1$ change in discounts is evaluated at average emergency room revenues over total revenues for 1984 and 1988. 